\title{
CAPILLARY GAS CHROMATOGRAPHICAL ANALYSIS AND MASS SPECTROMETRIC IDENTIFICATION OF POLYCYCLIC AROMATIC HYDROCARBON METABOLITES FROM BIOLOGICAL MATERIALS
}

\author{
Jürgen Jacob* and Gernot Grimmer \\ Biochemisches Institut für Umweltcarcinogene \\ 2070 Ahrensburg-Grosshansdorf, FRG
}

\begin{abstract}
SUMMARY
Supplementary to HPLC, capillary gas chromatography (CGC) can be used in combination with mass spectrometry (MS) for the characterization and identification of polycyclic aromatic hydrocarbon (PAH) metabolites from various biological systems. The main advantage of this technique can be seen in (a) the high resolution of CGC which is superior to HPLC, (b) the predictability of response factors according to the dependence of the FID-signals on the carbon content, and (3) the far-reaching and readily obtainable information on the structure of metabolites by MS.

A disadvantage is that volatility of the metabolites is required and that extremely polar compounds (such as glucuronides, sulfates, etc.) cannot be analyzed by this method. These problems can be partially overcome by derivatizing the metabolites.
\end{abstract}

\section{INTRODUCTION}

During the past decade substantial work on the metabolism of PAH in eukaryotic and procaryotic organisms has been carried out which has improved our understanding of PAH-induced carcinogenesis. Most investigators have used high performance liquid chromatography (HPLC) for analyzing the metabolite profiles of various PAH in different biological systems. Analysis of benzo(a)pyrene metabolism by 
means of HPLC has been reviewed by Selkirk /1/ and by Yang et al. $/ 2 /$. For the HPLC separation of critical pairs such as 1- and 3-hydroxybenzo(a)pyrene multifold chromatography is required. The same holds true for various trans-dihydrodiols of benz(a)anthracene $/ 3 /$. The primary metabolism of a number of other environmentally relevant and/or carcinogenic PAH has also been studied by HPLC, e.g. fluorene $\mid 4 /$, phenanthrene $\mid 5 /$, fluoranthene $/ 6 /$, chrysene $/ 7 /, 5$-methylchrysene $18 /, \quad 7,12$-dimethylbenz(a)anthracene $/ 9,10 /$, benzo(c)phenanthrene $/ 11 /$, cyclopenta(cd)pyrene $/ 12 /$, cholanthrene $/ 13 /$, and 3-methylcholanthrene $/ 14 /$, benzo(e)pyrene $/ 15 /$, benzo(b)-, $-(j)$-, and $-(k) f l u o r-$ anthene $/ 16,17 /$, indeno(1,2,3-cd)pyrene $/ 18,19 /$, di-benz(a,h)anthracene $/ 20 /$, dibenzo(a,h)- and dibenzo(a,i)pyrene $/ 21 /$.

For the analysis of the secondary metabolism of PAH forming water-soluble products such as glucuronides, sulfates, glutathion-, protein-, and DNA-conjugates HPLC is the most used technique. The hydrophilic metabolites of benzo(a)pyrene have been thoroughly investigated by many authors, e.g. Baird et al. $/ 22 /$ and by MacLeod et al. $/ 23 /$.

HPLC was the most commonly available method at the time in those laboratories initially involved in PAH metabolism studies. This may explain why CGC and GC/MS have been neglected for such a long time in this field. To avoid tailing effects and decomposition primary metabolites such as phenols and dihydrodiols have to be converted to acylates, trimethylsilyl or methyl ethers. The elaboration of the derivatization method has delayed the application of the CGC technique to metabolic studies so that only a few attempts have been made /e.g. 24-27/ until recently.

This paper summarizes GC and GC/MS studies of the metabolism of polycyclic aromatic compounds (PAC) such as phenanthrene, pyrene, benz(a)anthracene, chrysene, benzo(e)pyrene, indeno(1,2,3-cd)pyrene, benz(a)- and benz(c)acridine, benzo(b)naphtho(1,2-d)-, -(2,1-d)- and $-(2,3-d)$ thiophene as well as triphenyleno(4,5-bcd)thiophene).

\section{METHODOLOGY}

The general scheme for isolation and characterization or identification of PAH metabolites requires (a) extraction and clean-up, (b) deriva- 
tization by conversion to trimethylsilyl ethers, (c) gas chromatographic separation and (d) mass spectrometric analysis. For special cases, when, for instance, only the analysis of phenols from urine samples is demanded, an alternative method can be recommended during which phenols are converted into phenolmethyl ethers by diazomethane treatment. The latter can be analyzed readily by GC/MS (see under $f$ ).

\section{a. Clean-up by chromatography on Sephadex LH 20}

Prior to GC/MS, PAH metabolites together with the unconverted PAH substrates had to be enriched from biological systems (tissues, microsomes, cell or tissue cultures) by extraction preferably with ethyl acetate under slightly acidic conditions $(\mathrm{pH} \leqslant 3)$ in order to extract phenols. After washing this extract with water, it was cautiously evaporated almost to dryness and then chromatographed on Sephadex LH 20 with isopropanol as elutant to get rid of non-aromatic compounds and most of the laboratory contaminants. The elution volumes for a number of $\mathrm{PAH}$, azaarenes, nitro-PAH, and thiaarenes are listed in Table 1. The fraction eluted before the unconverted PAH substrate is discarded. Trans-dihydrodiols and te trols require about $10 \%$ and phenols about $30 \%$ larger elution volumes than the base PAH. In order not to lose any of the metabolites possibly formed, the fractions are generously dimensioned $(10-20 \mathrm{~mL}$ prior to when the substrate appears and at least $100 \mathrm{~mL}$, or preferably $150 \mathrm{~mL}$, after it has disappeared from the column).

\section{b. Preparation of the sample for $C G C$ (derivatization)}

The Sephadex LH 20 column eluate is evaporated and the residue dissolved in $10 \mu \mathrm{L}$ toluene. To this solution $8 \mu \mathrm{L}$ of a mixture of Trisil (Pierce) and N,O,bis-(trimethylsilyl)trifluoroacetamide (BSTFA Pierce) $(1: 1 ; \mathrm{v}: \mathrm{v})$ is added. The silylation is complete after $45 \mathrm{~min}$ at $45^{\circ} \mathrm{C}$. Due to possible decomposition by moisture it is advantageous to carry out the GC analysis immediately after derivatization. However, silylated PAH-metabolites can be stored under nitrogen in the dark at $-10^{\circ} \mathrm{C}$ for at least 5 days without any detectable decomposition. 
Elution volumes of various $\mathrm{PAH}$, azaarenes, nitro-PAH and thiaarenes on a Sephadex LH 20 column ( $10 \mathrm{~g}$; isopropanol as elutant).

\begin{tabular}{|c|c|}
\hline Compound & Elution volume (ml) \\
\hline \multicolumn{2}{|l|}{ PAH } \\
\hline Anthracene & $38-50$ \\
\hline Phenanthrene & $38-50$ \\
\hline Fluoranthene & $48-63$ \\
\hline Pyrene & 48- 63 \\
\hline Benzofluorenes $(a+b+c)$ & $51-63$ \\
\hline Benzo(ghi)fluoranthene & 56- 71 \\
\hline Cyclopenta(cd)pyrene & $60-78$ \\
\hline Benz(a)anthracene & $60-78$ \\
\hline Chrysene & $60-78$ \\
\hline Benzofluoranthenes $(b+j+k)$ & $72-90$ \\
\hline Benzo(a)pyrene & 73. 93 \\
\hline Benzo(e)pyrene & 78- 93 \\
\hline Perylene & $83-106$ \\
\hline Indeno(1,2,3-cd)fluoranthene & $84-107$ \\
\hline Indeno(1,2,3-cd)pyrene & $84-107$ \\
\hline Benzo(b)chrysene & $84-118$ \\
\hline Anthanthrene & $88-113$ \\
\hline Benzo(ghi)perylene & $90-118$ \\
\hline Coronene & $104-140$ \\
\hline \multicolumn{2}{|l|}{ Azaarenes } \\
\hline Acridine & $31-51$ \\
\hline Benzo(f)quinoline & $35-55$ \\
\hline Benz(a)acridine & 43- 67 \\
\hline Benz(c)acridine & $50-77$ \\
\hline Carbazol & $51-80$ \\
\hline Dibenz $(\mathbf{a}, \mathbf{j})$ acridine & $59-90$ \\
\hline Benzo(c)carbazol & $80-113$ \\
\hline Dibenzo $(c, g)$ carbazol & $93-140$ \\
\hline \multicolumn{2}{|l|}{ Nitro-PAH } \\
\hline 1-Nitronaphthalene & $50-63$ \\
\hline 2-Nitronaphthalene & $50-63$ \\
\hline 2-Nitrofluorene & 52- 69 \\
\hline 9-Nitroanthracene & 52- 72 \\
\hline 3-Nitrofluoranthene & 57- 82 \\
\hline 1-Nitropyrene & $59-85$ \\
\hline \multicolumn{2}{|l|}{ Thiaarenes } \\
\hline Benzo(b)naphtho(1,2-d)thiophene & 53- 78 \\
\hline Benzo(b)naphtho( 2,1 d)thiophene & 48- 68 \\
\hline Benzo(b)naphtho(2,3-d)thiophene & 53- 76 \\
\hline Triphenyleno( 4,5-bcd)thiophene & $68-95$ \\
\hline
\end{tabular}




\section{c. Capillary gas chromatography (CGC)}

For the GC analysis, $25-50 \mathrm{~m}$ (0.2-0.4 mm inner diameter) capillaries coated with dimethylpolysiloxane (e.g. SE-30, OV 101, OV 1), 95\% dimethyl-/ 5\% diphenylpolysiloxane (e.g. SE-52, SE-54) and comparable materials or chemically bound fused silica columns (e.g. CP sil 5 CB) are used. It is important to use all glass systems to avoid decomposition of TMS-ethers during GC, especially in the injection port. On-column and cold injection are the recommended inlet systems. Samples may be injected for instance at $100^{\circ} \mathrm{C}$ column temperature held for 5 or $10 \mathrm{~min}$ at that temperature to let the solvent and the excess of silylation reagent pass through the column. Thereafter a temperature program of $100-260^{\circ} \mathrm{C}$ with $2^{\circ} \mathrm{C} / \mathrm{min}$ can be chosen. Sometimes it is advantageous to start with a rapid program of $30^{\circ} \mathrm{C} / \mathrm{min}$ from $100-160^{\circ} \mathrm{C}$ followed by a flat temperature program of $1.5^{\circ} \mathrm{C}$ or $2^{\circ} \mathrm{C} / \mathrm{min}$ from $160 \cdot 270^{\circ} \mathrm{C}$. Helium is used as a carrier gas with flow rates of $20-25 \mathrm{~cm} / \mathrm{sec}$ (equal to $2-3 \mathrm{~mL} / \mathrm{min}$ ). To minimize peak tailing a post-column acceleration with argon between the column outlet and the detector system (FID) is recommended. To avoid detector coating by the excess of the silylation reagent, which may decrease the sensitivity, the electrode is removed for the first 5-10 minutes during which no metabolite peaks are expected. About $0.1 \mathrm{ng}$ is the limit of detection for a well adjusted GC system.

\section{d. Mass spectrometry (MS)}

Double focussing MS is advantageous but not obligatory. For optimum results the same GC equipment as mentioned under $\mathrm{c}$. is required. To avoid an unnecessary burden of the ion source by the solvent and the silylation reagent of the sample, the interface between the GC and MS is not connected before 5-7 minutes after injection to blend out these components. Thus, a large sample of a total volume of $5-10 \mu \mathrm{L}$ can be used. Mass spectra are mostly recorded at $70-80 \mathrm{eV}$ to obtain intense fragmentation. Parent peak spectrometry, however, is carried out at $20 \mathrm{eV}$. 


\section{e. Reference materials}

Various PAH, azaarenes and thiaarenes can be obtained from the Commission of the European Communities, Community Bureau of Reference - BCR, 200 Rue de la Loi, B-1049 Brussels, in high grade purity $(>99.0 \%)$ as reference standards. From this collection indeno(1,2,3-cd)fluoranthene has been found to be an excellent internal standard; in the low boiling range benzo(c)phenanthrene or 3,6-dimethylphenanthrene can be used as internal standards. However, there is a lack of PAH-metabolite standard materials and only a few PAH phenols are commercially available. A larger collection of PAHmetabolites can be obtained in milligram amounts from the NCI Chemical Repository, Bethesda, USA.

\section{f. Identification of phenols as phenolmethyl ethers (methoxy-PAH)}

For determination of PAH-metabolites in urine an alternative method can be used which allows the quantitative GC analysis of phenols after methylation in form of the phenol methyl ethers (methoxy-PAH).

\section{RESULTS AND APPLICATIONS}

\section{a. Capillary gas chromatography}

CGC of trimethylsilyl ethers of PAH metabolites has been successfully applied in the separation of isomers. In case of phenanthrene the various phenol and dihydrodiol TMS-ethers exhibit differences in retention times relative to the parent PAH (RRT) which allow an almost complete separation from each other. The RRT-values of the phenanthrene metabolites are listed in Table 2 and a gas-chromatogram of a separation of some of them is presented in Figure 1.

It seems not to be accidental that the 4-isomer (followed by 9-isomer) exhibits the shortest RRT; so far as is known, this holds true for several PAH, the OTMS-substituent of which is located in the bay-region. This effect may be due to the more compact structure in 


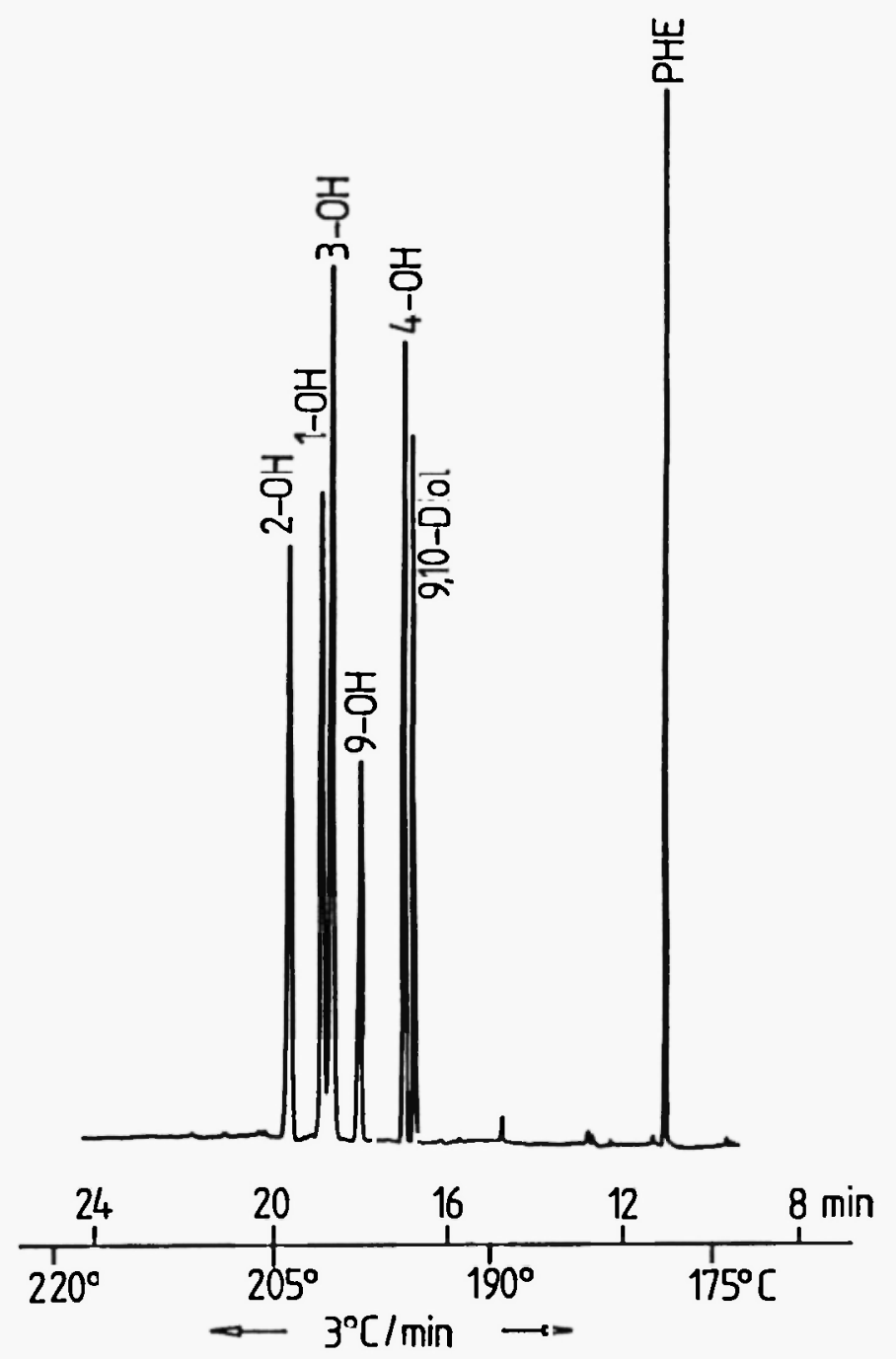

Fig. 1: CGC-separation of a synthetic mixture of phenanthrene metabolites after silylation (CGC conditions: Gas chromatograph Perkin-Elmer 8320 on column injection, column SE 54 chemical bound, $25 \mathrm{~m} \times 0.32 \mathrm{~mm}, 0.25$ $\mu \mathrm{m}$ film thickness, carrier gas helium: $2 \mathrm{ml} / \mathrm{min}$, FID-temperature $280^{\circ} \mathrm{C}$. Note: According to different GC-conditions the elution sequence of the metabolites differs from that given in Table 2. 
GC retention times of various phenanthrene metabolites (relative to phenanthrene) after silylation ( $25 \mathrm{~m} \times 0.4 \mathrm{~mm}$ glass capillary column coated with CP sil $5(0.8 \mu \mathrm{m}$ film thickness) $/ 28$ /

\section{Compound}

RRT

Phenanthrene

1-Hydroxyphenanthrene

2-Hydroxyphenanthrene

3-Hydroxyphenanthrene

4-Hydroxyphenanthrene

9-Hydroxyphenanthrene

trans-1,2-dihydroxy-1,2-dihydrophenanthrene

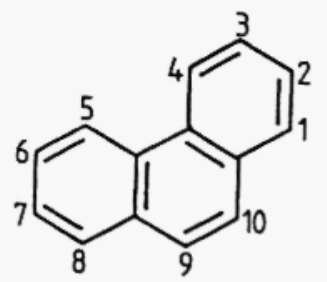

comparison to the more stretched molecular shape to be expected, e.g. for the 2-phenanthrol TMS-ether. As a consequence, among the dihydrodiol-TMS-ethers the trans-1,2-dihydrodiol shows the greatest RRT. However, exceptions to this rule have also been observed. Cis-isomers of the dihydrodiols generally exhibit larger retention times than trans-isomers.

The aforementioned findings have been confirmed with the phenols and dihydrodiols of benz(a)anthracene as can be seen from Table 3 . The TMS-ethers of all these metabolites can be separated by CGC as shown in Figure 2. 


\section{TABLE 3}

GC retention times of various benz(a)anthracene metabolites (relative to benz(a)an thracene) after silylation ( $25 \mathrm{~m} \times 0.3 \mathrm{~mm}$ glass capillary column coated with CP sil $5(0.8 \mu \mathrm{m}$ film thickness $) / 29$ )

\begin{tabular}{lc}
\hline Compound & RRT \\
\hline Benz(a)anthracene & 1.000 \\
1-Hydroxybenz(a)anthracene & 1.171 \\
2-Hydroxybenz(a)anthracene & 1.228 \\
3-Hydroxybenz(a)anthracene & 1.258 \\
4-Hydroxybenz(a)anthracene & 1.240 \\
5-Hydroxybenz(a)anthracene & 1.218 \\
8-Hydroxybenz(a)anthracene & 1.215 \\
9-Hydroxybenz(a)anthracene & 1.259 \\
10-Hydroxybenz(a)anthracene & 1.253 \\
11-Hydroxybenz(a)anthracene & 1.184 \\
trans-1,2-Dihydroxy-1,2-dihydrobenz(a)anthracene & 1.127 \\
trans-3,4-Dihydroxy-3,4-dihydrobenz(a)anthracene & 1.312 \\
trans-5,6-Dihydroxy-5,6-dihydrobenz(a)anthracene & 1.100 \\
cis-5,6-Dihydroxy-5,6-dihydrobenz(a)anthracene & 1.110 \\
trans-8,9-Dihydroxy-8,9-dihydrobenz(a)anthracene & 1.290 \\
trans-10,11-Dihydroxy-10,11-dihydrobenz(a)anthracene & 1.260
\end{tabular}<smiles>c1ccc2cc3ccccc3cc2c1</smiles>

The RRT for chrysene metabolites are summarized in Table 4.

In Figure 3, a CGC separation of some possible primary chrysene metabolites is shown.

CGC data are also available for some metabolites of pyrene, benzo(e)pyrene, and indeno(1,2,3-cd)pyrene; they are listed in Table 5. 


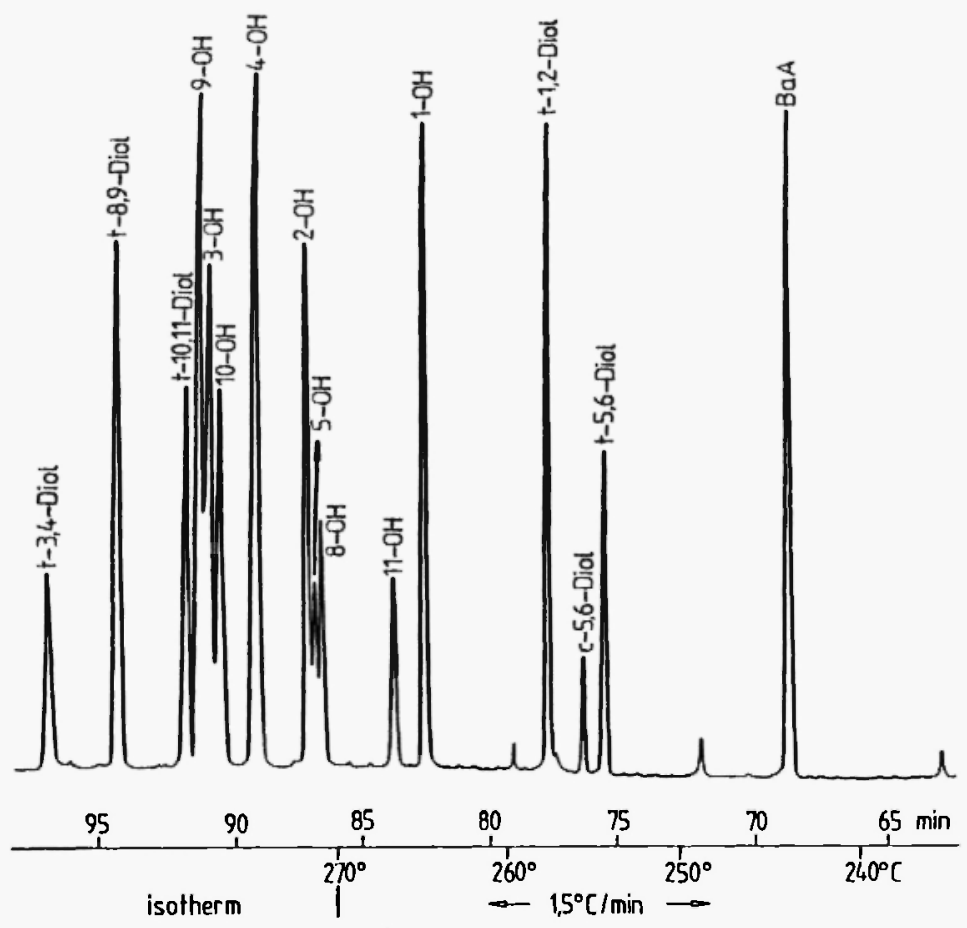

Fig. 2: CGC-separation of a mixture of benzlalanthracene and its metabolites after silylation (CGC-conditions are given in Table 3 ). 


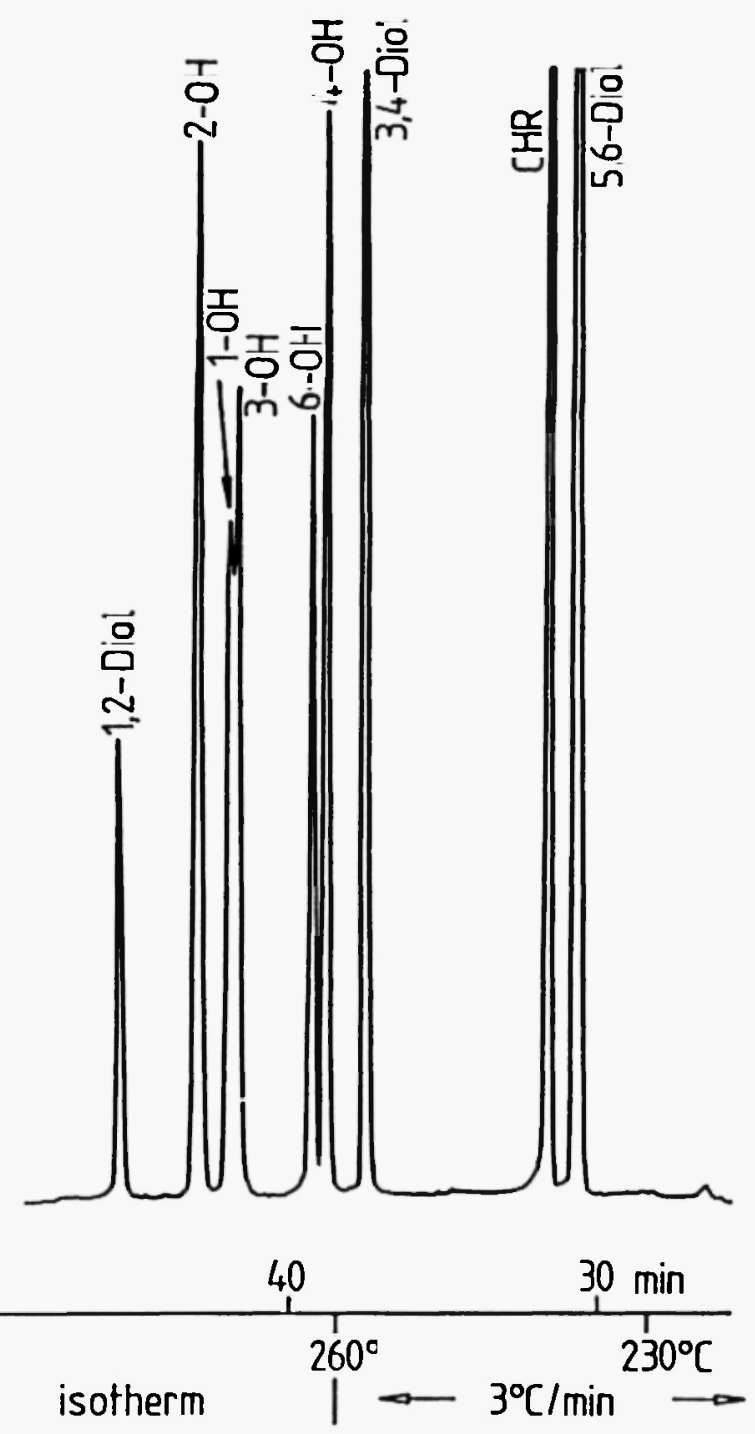

Fig. 3: CGC-separation of a mixture of chrysene and its metabolites after silylation (CGC-conditions are given in Table 4). 
GC retention times of various chrysene metabolites (relative to chrysene) after silylation ( $25 \mathrm{~m} \times 0.3 \mathrm{~mm}$ glass capillary column coated with $\mathrm{CP}$ sil $5,0.8 \mu \mathrm{m}$ film thickness) $/ 30 /$.

\begin{tabular}{lc}
\hline Compound & RRT \\
\hline Chrysene & 1.000 \\
1-Hydroxychrysene & 1.192 \\
2-Hydroxychrysene & 1.211 \\
3-Hydroxychrysene & 1.188 \\
4-Hydroxychrysene & 1.133 \\
6-Hydroxychrysene & 1.143 \\
trans-1,2-Dihydroxy-1,2-dihydrochrysene & 1.261 \\
trans-3,4-Dihydroxy-3,4-dihydrochrysene & 1.108 \\
trans-5,6-Dihydroxy-5,6-dihydrochrysene & 0.988
\end{tabular}<smiles>c1ccc2c(c1)ccc1c3ccccc3ccc21</smiles>

Figure 4 shows that the separation of some isomers may be difficult in the case of the benzo(e)pyrene phenol TMS-ethers (e.g. 1-; 4- and 10-isomer).

The relative retention time of a number of benzo(a)pyrene metabolites can be calculated from the data reported by Takahashi $e t$ al. $/ 25 /$. They are presented in Table 6 . The bay-region phenols (10- and 11-hydroxybenzo(a)pyrene) were found to have the lowest values, whereas the 8-hydroxybenzo(a)pyrene exhibits the highest RRT. Slight differences in the ranking of RRTs were found when two different stationary phases were applied (Dexsil-300 and OV-1) /25/. Although cis-dihydrodiol-TMS-ethers generally exhibit greater RRT than the 

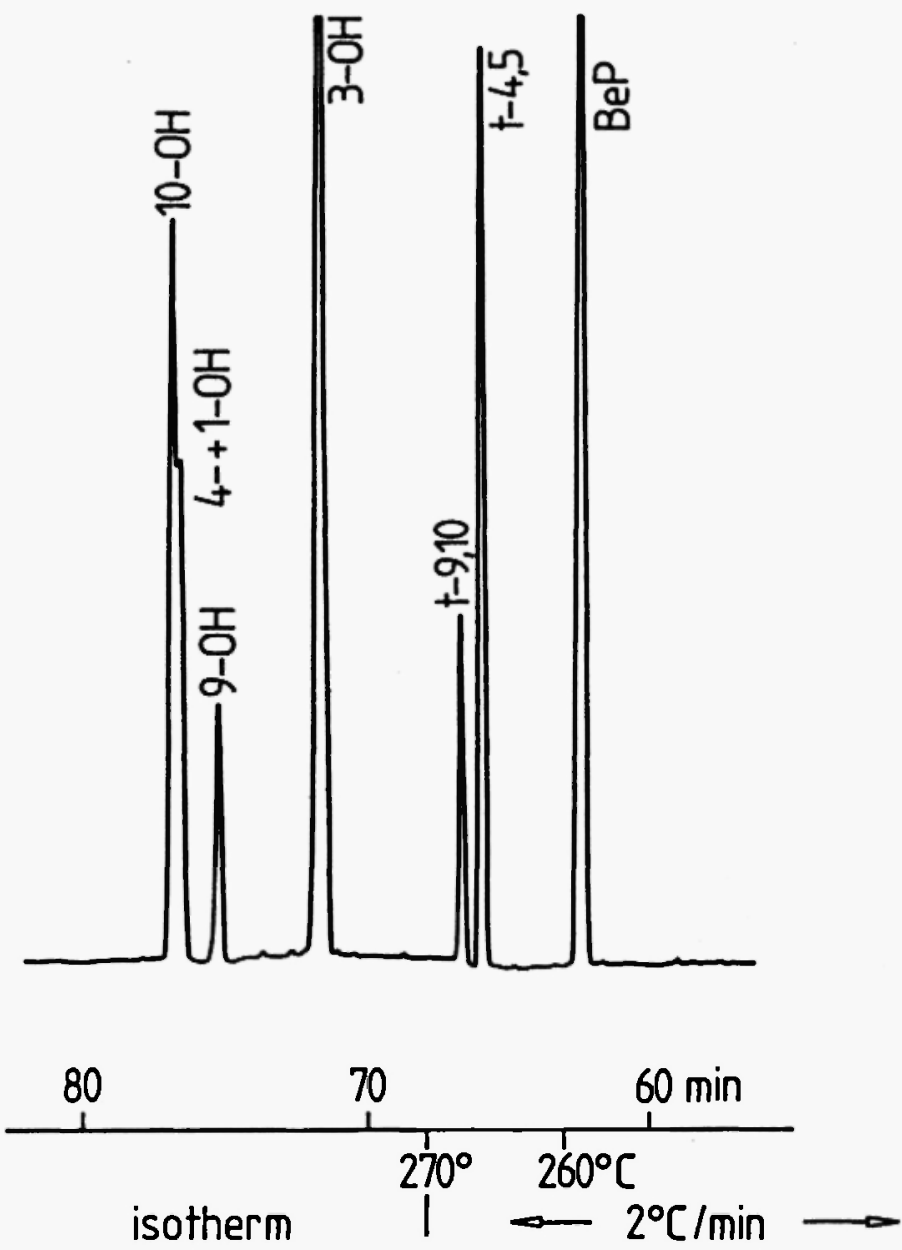

Fig. 4: CGC-separation of a mixture of benzo(e)pyrene and its metabolites after silylation (CGC-conditions are given in Table 5). 


\section{TABLE 5}

Relative GC retention times of some pyrene, benzo(e)pyrene, and indeno(1,2,3-cd)pyrene metabolites after silylation ( $25 \mathrm{~m} \times 0.4 \mathrm{~mm}$ glass capillary column coated with $\mathrm{CP}$ sil 5; film thickness $0.8 \mu \mathrm{m}$ ) /31-34/.

\section{Pyrene}

1-Hydroxypyrene

1,6-Dihydroxypyrene

1,8-Dihydroxypyrene

trans 4,5 -Dihydroxy 4,5 -dihydropyrene

1-Hydroxybenzo(e)pyrene

3-Hydroxybenzo(e)pyrene

4-Hydroxybenzo(e)pyrene

9-Hydroxybenzo(e)pyrene

10-Hydroxybenzo(e)pyrene

trans 4,5-Dihydroxy 4,5-dihydrobenzo(e)pyrene

trans-9,10-Dihydroxy-9,10-dihydrobenzo(e)pyrene

Indeno(1,2,3-cd)pyrene

2-Hydroxy-indeno(1,2,3-cd)pyrene

6-Hydroxy-indeno(1,2,3-cd)pyrene

\section{$(1,2,3$-cd)pyrene}

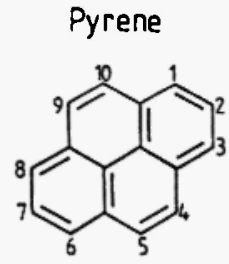<smiles>CC(C)(C)OC(=O)c1cc2c3ccccc3c3ccccc4c(ccc3)c3c2c(c1)c43</smiles><smiles></smiles> 


\section{TABLE 6}

GC retention times of various benzo(a)pyrene metabolites (relative to benzo(a)pyrene) after silylation ( $1 \mathrm{~m} \times 2 \mathrm{~mm}$ packed column with $2 \%$ OV-1 or $2 \mathrm{~m}$ x $2 \mathrm{~mm}$ packed column with $6 \%$ Dexsil -300 on Chromsorb $\mathrm{W}$, operated at $250^{\circ} \mathrm{C}$ (OV-1) and $290^{\circ} \mathrm{C}$ (Dexsil-300)) /25/

\begin{tabular}{lll}
\hline Metabolite & Dexsil-300 & OV-1 \\
\hline Benzo(a)pyrene & & \\
Benzo(a)pyrene & 1.00 & 1.00 \\
1-Hydroxybenzo(a)pyrene & 2.73 & 2.73 \\
2-Hydroxybenzo(a)pyrene & 2.73 & 3.31 \\
3-Hydroxybenzo(a)pyrene & 2.73 & 3.42 \\
4-Hydroxybenzo(a)pyrene & 2.35 & 2.92 \\
5-Hydroxybenzo(a)pyrene & 2.05 & 2.61 \\
6-Hydroxybenzo(a)pyrene & 2.00 & 2.44 \\
7-Hydroxybenzo(a)pyrene & 2.38 & 2.97 \\
8-Hydroxybenzo(a)pyrene & 3.05 & 3.67 \\
9-Hydroxybenzo(a)pyrene & 2.62 & 3.28 \\
10-Hydroxybenzo(a)pyrene & 1.92 & 2.42 \\
11-Hydroxybenzo(a)pyrene & 1.59 & 2.11 \\
12-Hydroxybenzo(a)pyrene & 1.95 & 2.47 \\
& & \\
Dihydroxybenzo(a)pyrene & & \\
1,6-Dihydroxybenzo(a)pyrene & & \\
3,6-Dihydroxybenzo(a)pyrene & 4.19 & 6.11 \\
4,5-Dihydroxybenzo(a)pyrene & 3.65 & 5.58 \\
6,12-Dihydroxybenzo(a)pyrene & 2.14 & 3.58 \\
7,10-Dihydroxybenzo(a)pyrene & 2.81 & 4.69 \\
11,12-Dihydroxybenzo(a)pyrene & 3.24 & 4.94 \\
Dihydrodihydroxybenzo(a)pyrene & 1.24 & 2.08 \\
cis-4,5-Dihydroxy 4,5-dihydro-BaP & & \\
trans-4,5-Dihydroxy-4,5-dihydro-BaP & 0.57 & 1.44 \\
cis-7,8-Dihydroxy-7,8-dihydro-BaP & 1.73 & 3.03 \\
trans-7,8-Dihydroxy-7,8-dihydro-BaP & 2.24 & 3.78 \\
trans-9,10-Dihydroxy-9,10-dihydro-BaP & 0.65 & 1.53 \\
cis-11,12-Dihydroxy-11,12-dihydro-BaP & 0.32 & 1.08 \\
trans-11,12-Dihydroxy-11,12-dihydro-BaP & 0.08 & 0.39
\end{tabular}


$7 \beta, 8 \alpha, 9 \beta, 10 \alpha$-Tetrahydroxy-7,8,9,10-*

$7 \beta, 8 \alpha, 9 \beta, 10 \beta-$ Tetrahydroxy $-7,8,9,10-*$

$2.84 \quad 7.22$

$7 \beta, 8 \alpha, 9 \alpha, 10 \alpha$-Tetrahydroxy-7,8,9,10-*

$1.70 \quad 4.94$

$7 \beta, 8 \alpha, 9 \alpha, 10 \alpha$-Tetrahydroxy-7,8,9,10-*

Benzo(a)pyrene-1 ,6-quinone

Benzo(a)pyrene-3,6-quinone

Benzo(a)pyrene-4,5-quinone

$4.92 \quad 4.03$

Benzo(a)pyrene-6,12-quinone

$2.97 \quad 2.81$

Benzo(a)pyrene-7,10-quinone

$\begin{array}{ll}1.86 & 1.97\end{array}$

Benzo(a)pyrene-11,12-quinone

4.54

* tetrahydrobenzo(a)pyrene<smiles>c1ccc2c(c1)cc1ccc3cccc4ccc2c1c34</smiles>

corresponding trans-isomers, the opposite was reported for the two isomers of the 7,8-benzo(a)pyrenedihydrodiol $/ 25 /$.

CGC retention data of some metabolites derived from heterocyclic PAC such as benz(a)- and benz(c)acridine as well as various thiaarenes are presented in Table 7.

It has to be kept in mind that the RRT depend to a great extent on the CGC conditions (temperature, temperature program, column impregnation) so that even the sequence of various metabolites may occasionally differ under varying conditions.

Since the response of FID generally used in CGC strongly depends linearly on the carbon content of the molecule, identical intensities of the signals are expected and observed for a certain class of compound (e.g. phenol TMS-ethers or dihydrodiol TMS-ethers). An example shows that the relative responses increase with the degree of oxygenation for a 
TABLE 7

Relative GC retention times of metabolites of some heterocyclic PAC after silylation (except the thiaarene metabolites) $(25 \mathrm{~m} \mathrm{x} 0.37 \mathrm{~mm}$ glass capillary column coated with CP sil 5; film thickness $0.8 \mu \mathrm{m}$ ) /34-37/

Metabolite

RRT

Benz(a)acridine

1.000

trans-3,4-Dihydroxy-3,4-dihydrobenz(a)acridine

1.395

trans-5,6-Dihydroxy-5,6-dihydrobenz(a)acridine

1.108

Benz(c)acridine

1.000

trans-3,4-Dihydroxy-3,4-dihydrobenz(c)acridine

1.444

trans-5,6-Dihydroxy-5,6-dihydrobenz(c)acridine

1.155

3,4,5,6-Tetrahydroxy-3,4,5,6-tetrahydro-BcAc

1.861

Benzo(b)naphtho(1,2-d)thiophene

1.000

Benzo(b)naphtho(1,2-d)thiophene-7,7-dioxide

Benzo(b)naph tho(2,1-d)thiophene

1.000

Benzo(b)naphtho(2,1-d) thiophene-11,11-dioxide $\quad 1.360$

Benzo(b)naphtho(2,3-d)thiophene

1.000

Benzo(b)naph tho(2,3-d)thiophene-5,5-dioxide

Benzo(b)naphtho(2,3-d)thiophene-6,11-quinone

Triphenyleno $(4,5$-bed)thiophene

1.000

Triphenyleno(4,5-bcd)thiophene-4,4-dioxide

Benzlalacridine Benz(c)acridine Benzolblnaphtho(1,2-d)thiophene<smiles>c1ccc2nc3ccc4ccccc4c3cc2c1</smiles><smiles>c1ccc2nc3c4ccccc4cc-3ccc2c1</smiles><smiles>c1ccc2c(c1)ccc1sc3ccccc3c12</smiles>

Benzo(b)naphtho(2,1-d)thiophene

Benzolbluaphtho-<smiles>c1ccc2c(c1)ccc1c3ccccc3sc21</smiles(2,3-d)thiophene<smiles></smiles>

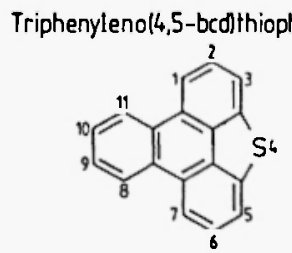


distinct PAH: in case of benz(a)anthracene the relative carbon content is $94.7 \%$; if the FID-signal for the base PAH is set to $100 \%$, the relative response for a phenol TMS-ether derived from a certain absolute amount of this PAH (e.g. 1 nanomole $=228 \mathrm{ng}$ ) should be 1.17 times this signal, since the molecular weight, and hence the carbon number per molecule, increases from 228 in benz(a) anthracene $\left(C_{18}=216\right)$ to 244 in case of the phenol and 316 in case of the phenol TMS-ether $\left(C_{21}\right.$ $\cong 252$ ). Accordingly, for the FID-signal a factor of $252 / 216=1.17$ is to be expected which, roughly, is what is found. In the case of dihydrodiol TMS-ethers this factor rises to 1.33. In Table 8, theoretical response factors for some types of metabolites derived from a number of PAH are listed.

Recoveries of phenols and dihydrodiols for the complete method including clean-up and CGC have been found to be about $90 \%$ with coefficients of variation between 5-8\%. GC recoveries (response) for the set of methoxyphenanthrenes have been measured recently $/ 38 /$ and found to lie between $91-106 \%$ with coefficients of variation of $2.4-4.1 \%$ (Table 9).

Relative retention times for a number of methoxy-PAH are summarized in Table 10.

Although the RRT values of methoxy-PAH do not always appear in the same order as those of the TMS-ethers, the bay-region substituted methoxy-PAH generally exhibit the shortest retention times.

\section{b. Mass spectrometry (MS)}

Apart from the molecular weight of the metabolites, many items of information on the molecule may be obtained by MS. In most cases, prominent molecular ions are observed, mainly base peaks in the case of the PAH phenol TMS-ethers (see Table 11) and most of the quinones. They are smaller in case of the TMS ethers of dihydrodiols, triols and tetrols.

For phenols, the ratio $\mathrm{M}-15 / \mathrm{M}-31$ is an indication of the location of the substituent. Sometimes low ratios are found for positions where a 5 - or 6-membered cyclic ion can be formed by elimination of $(2$ $\left.\mathrm{CH}_{3}+\mathrm{H}\right) / 28,33 /$ as in the case of 3-hydroxy-benzo(e)pyrene-TMS-ether ((a), Figure 5) or 4-hydroxy-phenanthrene-TMS-ether ((b), Figure 5), 


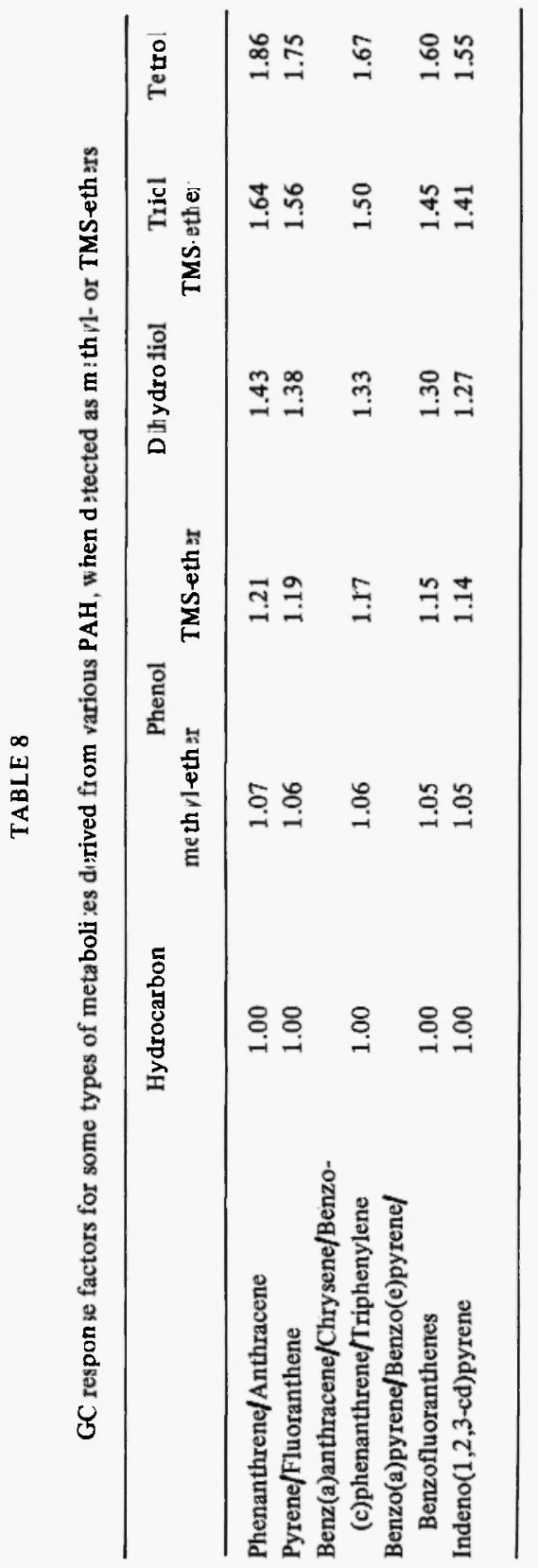




\section{TABLE 9}

GC recoveries and their variation coefficients of various methoxyphenanthrenes $(\mathrm{n}=6)$

\begin{tabular}{lrrrrrrrr}
\hline Compound & \multicolumn{3}{c}{ Recoveries } & & & & mean V (\%) \\
\hline 1-Methoxy-PHE & 104 & 14 & 105 & 99 & 103 & 100 & 101.8 & 2.44 \\
2-Methoxy-PHE & 96 & 95 & 100 & 97 & 105 & 102 & 99.2 & 3.90 \\
3-Methoxy-PHE & 98 & 90 & 95 & 95 & 95 & 98 & 95.2 & 3.08 \\
4-Methoxy-PHE & 101 & 102 & 98 & 100 & 106 & 95 & 100.3 & 3.71 \\
9-Methoxy-PHE & 92 & 98 & 90 & 90 & 87 & 90 & 91.2 & 4.07 \\
& & & & & & & & \\
\hline
\end{tabular}

\section{TABLE 10}

GC retention times of various methoxy-PAH (related to the base PAH ( $25 \mathrm{~m} \times 0.32$ $\mathrm{mm}$ ) Nordibond (chemical bound) SE-54, $0.25 \mu \mathrm{m}$ film thickness, fused silica; $110-185^{\circ} \mathrm{C}$ with $25^{\circ} \mathrm{C} / \mathrm{min}$, then $185^{\circ} \mathrm{C}-280^{\circ} \mathrm{C}$ with $2^{\circ} \mathrm{C} / \mathrm{min}$

\begin{tabular}{lr}
\hline Compound & RRT \\
\hline Phenanthrene & 1.000 \\
1-Methoxyphenanthrene & 1.585 \\
2-Methoxyphenanthrene & 1.604 \\
3-Methoxyphenanthrene & 1.548 \\
4-Methoxyphenanthrene & 1.503 \\
9-Methoxyphenanthrene & 1.558 \\
Pyrene & \\
1-Methoxypyrene & 1.693 \\
Chrysene & 1.000 \\
1-Methoxychrysene & 1.393 \\
2-Methoxychrysene & 1.404 \\
3-Methoxychrysene & 1.370 \\
4-Methoxychrysene & 1.341 \\
6-Methoxychrysene & 1.330 \\
Benzo(a)pyrene & 1.000 \\
3-Methoxybenzo(a)pyrene & 1.271 \\
9-Methoxybenzo(a)pyrene & 1.253 \\
\hline
\end{tabular}




\section{TABLE 11}

Main mass spectrometric fragments and their relative intensities of various PAH phenol TMS-ethers (recorded at $80 \mathrm{eV}$ )

\begin{tabular}{|c|c|c|c|c|c|}
\hline \multirow[t]{2}{*}{ Metabolite } & \multicolumn{5}{|c|}{ Relative intensities (\%) } \\
\hline & M & (M-15) & (M-31) & $\mathrm{m} / \mathrm{z} 73$ & M-15/M-31 \\
\hline 1-OTMS-PYR* & 100 & 29 & 14 & 72 & 2.1 \\
\hline 1,6-OTMS-PYR & 100 & 13 & 7 & 83 & 1.9 \\
\hline 1,8-OTMS-PYR & 100 & 10 & 4 & 59 & 2.5 \\
\hline 1-OTMS-BeP* & 10 & 23 & 21 & 25 & 1.1 \\
\hline 3-OTMS-BeP & 100 & 19 & 26 & 19 & 0.7 \\
\hline 4-OTMS-BeP & 100 & 19 & 17 & 21 & 1.1 \\
\hline 9-OTMS-BeP & 100 & 22 & 17 & 17 & 1.3 \\
\hline 10-OTMS-BeP & 100 & 21 & 3 & 17 & 7.0 \\
\hline 2-OTMS-INP* & 100 & 31 & 44 & 90 & 0.7 \\
\hline 6-OTMS-INP & 100 & 24 & 19 & 45 & 1.3 \\
\hline 7-OTMS-INP & 100 & 28 & 39 & 28 & 0.7 \\
\hline 8-OTMS-INP & 100 & 21 & 7 & 10 & 3.0 \\
\hline 9-OTMS-INP & 100 & 50 & 11 & 35 & 4.5 \\
\hline 1-OTMS-PHE* & 100 & 83 & 27 & 72 & 3.1 \\
\hline 2-OTMS-PHE & 100 & 94 & 9 & 22 & 10.4 \\
\hline 3-OTMS-PHE & 100 & 77 & 7 & 22 & 11.0 \\
\hline 4-OTMS-PHE & 100 & 43 & 47 & 45 & 0.9 \\
\hline 9-OTMS-PHE & 100 & 77 & 23 & 53 & 3.3 \\
\hline 1-OTMS-BaA* & 100 & 32 & 46 & 24 & 0.7 \\
\hline 2-OTMS-BaA & 100 & 47 & 10 & 29 & 4.7 \\
\hline 3-OTMS-BaA & 100 & 43 & 9 & 31 & 4.8 \\
\hline 4-OTMS-BaA & 100 & 42 & 32 & 38 & 1.3 \\
\hline 5-OTMS-BaA & 100 & 43 & 33 & 46 & 1.3 \\
\hline 8-OTMS-BaA & 100 & 41 & 26 & 42 & 1.6 \\
\hline 9-OTMS-BaA & 100 & 62 & 11 & 30 & 5.5 \\
\hline 10-OTMS-BaA & 100 & 59 & 9 & 34 & 6.6 \\
\hline 11-OTMS-BaA & 100 & 47 & 34 & 29 & 1.4 \\
\hline 1-OTMS-CHR* & 100 & 42 & 17 & 43 & 2.5 \\
\hline 2-OTMS-CHR & 100 & 52 & 22 & 90 & 2.4 \\
\hline 3-OTMS-CHR & 100 & 40 & 15 & 55 & 2.7 \\
\hline 4-OTMS-CHR & 100 & 50 & 46 & 55 & 1.1 \\
\hline 6-OTMS-CHR & 100 & 48 & 16 & 80 & 3.0 \\
\hline
\end{tabular}

*PYR: pyrene: BeP: benzo(e)pyrene; INP: indeno(1,2,3-cd)pyrene; PHE: phenar urene; BaA: benz(a)anthracene; CHR: chrysene. 
whereas high ratios are found in components with substituents in distal positions such as 2-hydroxy-phenanthrene-TMS-ether ((c), Figure 5) or 10-hydroxy-benzo(e)pyrene-TMS-ether ((d), Figure 5).

In dihydrodiol-TMS-ethers, the base peak is $\mathrm{m} / \mathrm{z} 73\left({ }^{+} \mathrm{Si}\left(\mathrm{CH}_{3}\right)_{3}\right), 147$ (tentatively $\left(\mathrm{CH}_{3}\right)_{2}{ }^{+} \mathrm{Si}-\mathrm{O}-\mathrm{Si}\left(\mathrm{CH}_{3}\right)_{3}$, or $191\left({ }^{+} \mathrm{CH}(\mathrm{OTMS})_{2}\right)$. Apart from these, intense fragments (M-15), (M-89), (M-90), and less intense fragments (M-103) and (M-178), can be observed. The intensity of the parent peak is between a few and up to $50 \%$ and more, but never becomes the base peak. The ratio $\mathrm{mz} 147 / 191$ is indicative of the position of the vicinal dihydroxy substitution. The ratio is $\gg 1$ for K-region dihydrodiol TMS-ethers and $<1$ (seldom $\approx 1$ ) in the case of non-K-region dihydrodiol-TMS-ethers. This might be a substantial help for their identification. In Table 12 the relative intensities of some fragments of various PAH-dihydrodiol-TMS-ethers are collected.

Dihydrodiolphenol-TMS-ether (triol-TMS-ether) behaves similarly to dihydrodiol derivatives. The base peak is found among $\mathrm{m} / \mathrm{z} 73,147$, 191. Again a ratio m/z 147/mz $191>1$ indicates a diol TMS- "partial structure" to be present in the K-region, whereas a ratio $<1$ indicates its absence in this position. Some of these spectrometric data on PAH-triol-TMS-ether are presented in Table 13.

Less intense parent peaks are observed in the mass spectra of PAH tetraol-TMS-ethers. Table 14 presents some MS data for six different individuals. From these it seems that elimination of a fragment with mass 204 which may be $\left(\mathrm{CH}_{3}\right)_{3} \mathrm{Si}-\mathrm{O}-\mathrm{HC}=\mathrm{CH}-\mathrm{O}-\mathrm{Si}\left(\mathrm{CH}_{3}\right)_{3}$ is preferred in stereo isomers having two quasi-equatorial or quasi-axial adjacent OTMS-groups since the fragment (M-204) is more intense in the $7 \beta, 8 \alpha$. $9 \beta, 10 \beta$-, the $7 \beta, 8 \alpha, 9 \alpha, 10 \beta$ - and the $7 \beta, 8 \alpha, 9 \alpha, 10 \alpha$ - than in the $7 \beta$, $8 \alpha, 9 \beta, 10 \alpha$-isomer of the four benzo(a)pyrene tetraols in Table 14 , the latter of which possess alternating OTMS-groups.

Quinones can readily be recognized from the fragments (M-28) and (M-56) deriving from CO-eliminations. Moreover, it seems that orthoquinones can be distinguished from para-quinones by the ratio of $M /(M-28)$ which is $>1$ in the latter and $<1$ in ortho-quinones (see Table 15).

Sulfoxides and sulfones, the main metabolites of thiaarenes, are mass spectrometrically characterized by a series of key ions, e.g. (M-29), (M-32), (M-45), (M-48), (M-66), and (M-77) corresponding to 

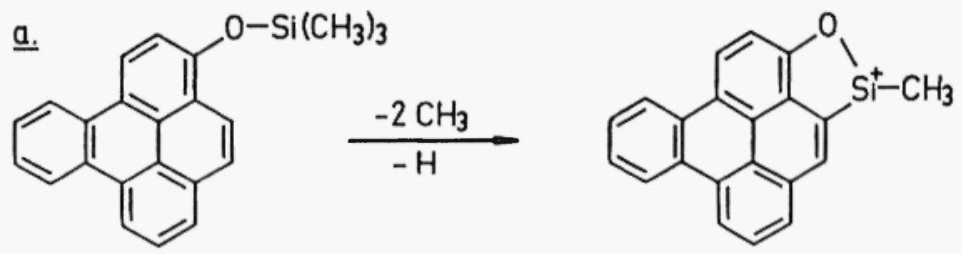

b.

$\left(\mathrm{CH}_{3}\right)_{3}-\mathrm{Si}-\mathrm{O}$<smiles>C[SiH2]c1cccc2ccc3ccccc3c12</smiles>

$\frac{-2 \mathrm{CH}_{3}}{-\mathrm{H}}$<smiles></smiles>

ㄷ.<smiles>C[SiH](C)Oc1ccc2c(ccc3ccccc32)c1</smiles><smiles></smiles>

Fig. 5: Mass spectrometric behaviour of some phenol TMS-ethers. 


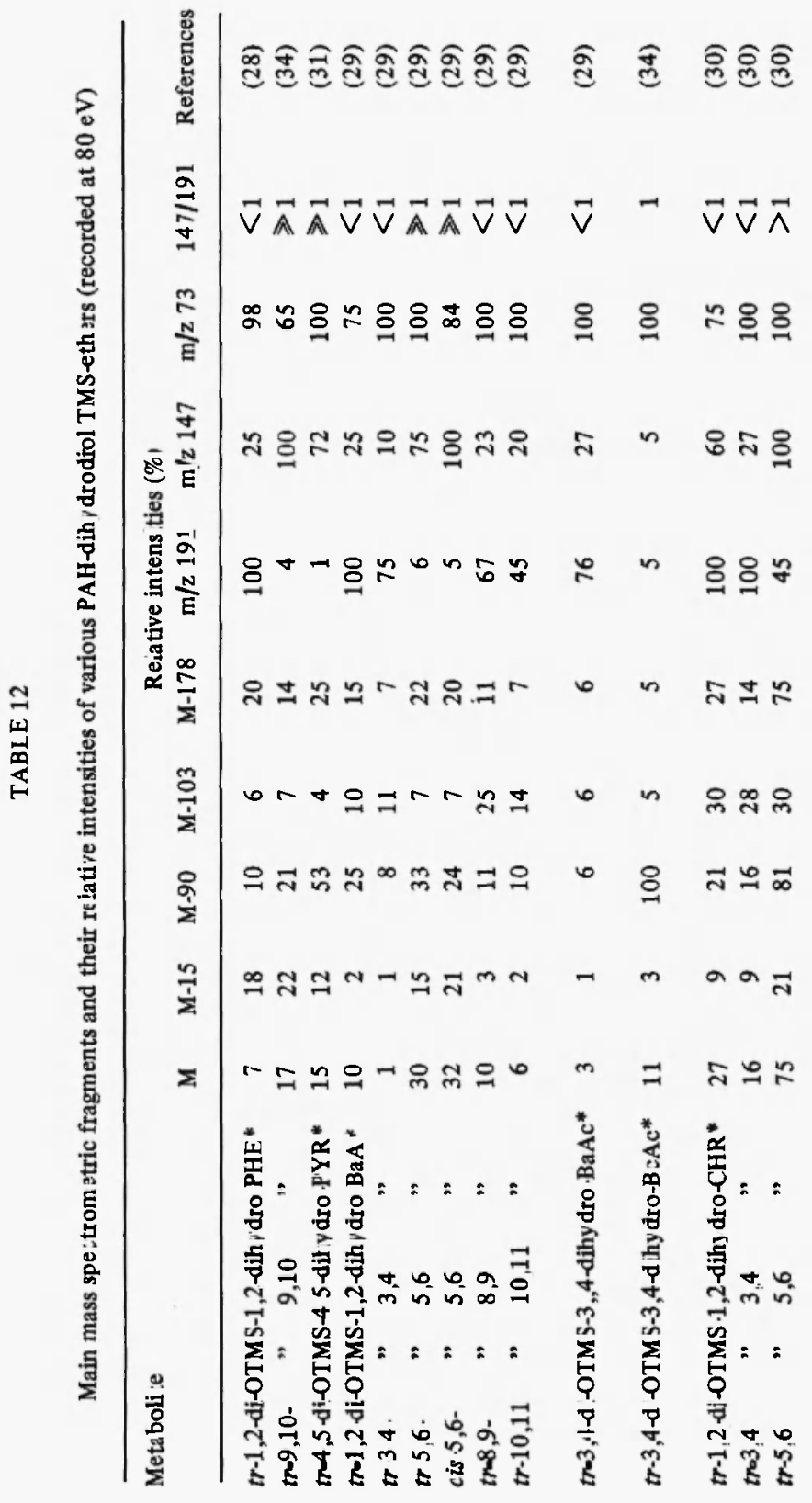




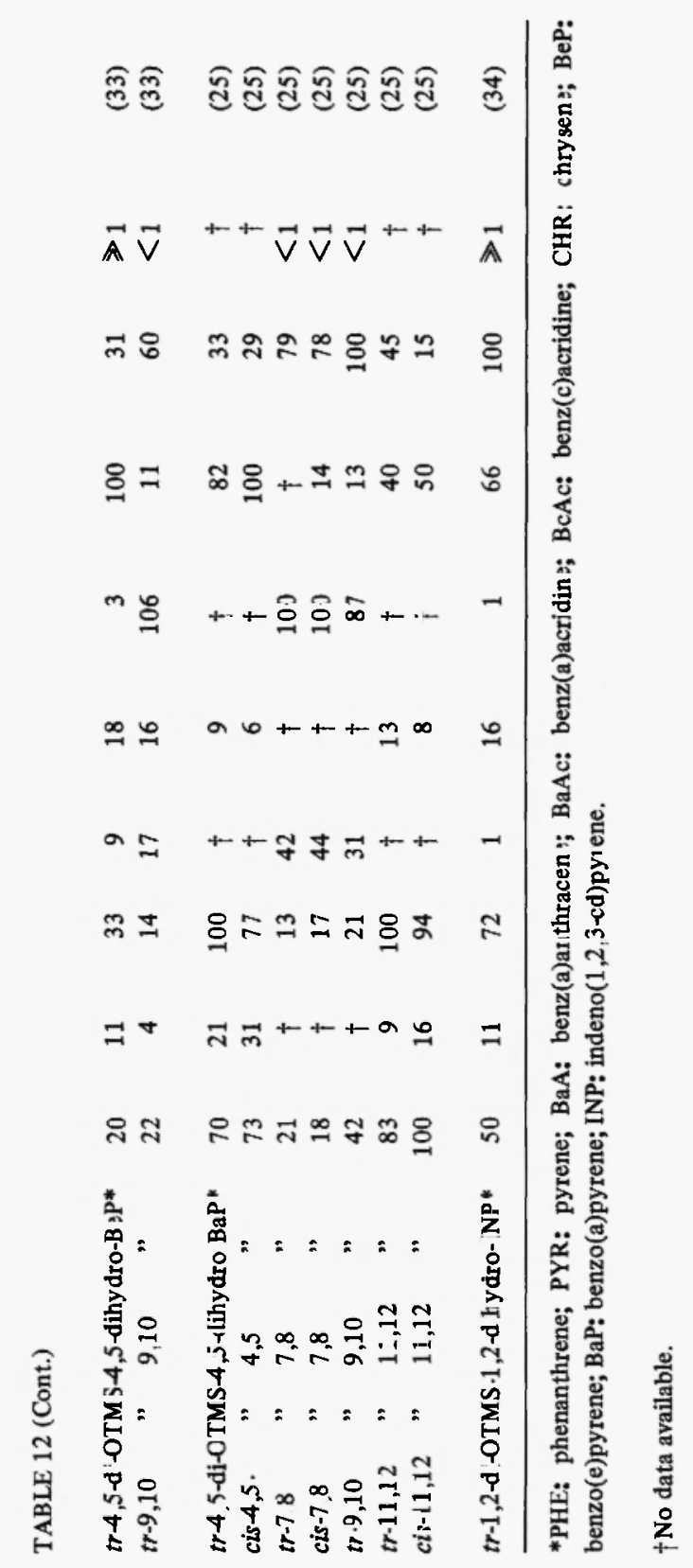




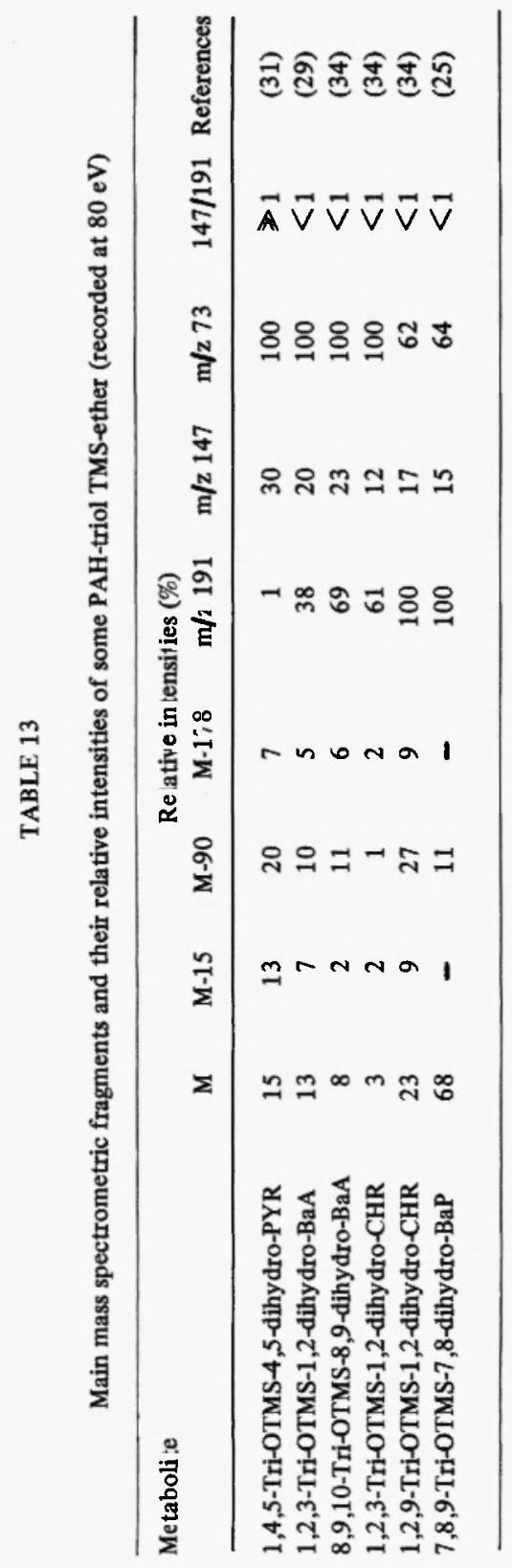




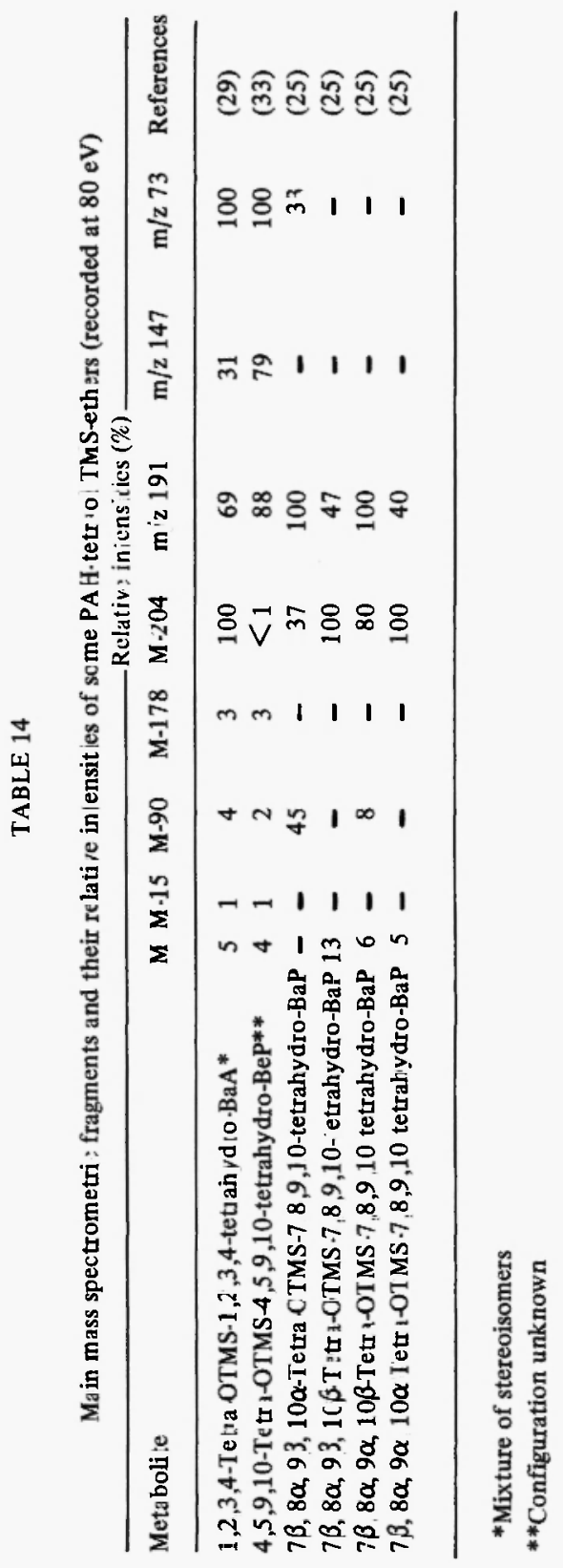


TABLE 15

Main mass spectrometric fragments and their relative intensities of some PAH quinones (recorded at $80 \mathrm{eV}$ )

\begin{tabular}{lrrrl}
\hline Metabolite & Relative intensities (\%) & & \\
& M & M-28 & M-56 & References \\
\hline Acenaphthene-1,2-quinone & 57 & 100 & 83 & $(34)$ \\
Anthracene-1,4-quinone & 100 & 21 & 55 & $(34)$ \\
Anthracene-9,10-quinone & 100 & 64 & 47 & $(34)$ \\
Phenanthrene-9,10-quinone & 35 & 100 & 52 & $(34)$ \\
Benz(a)anthracene-7,12-quinone & 100 & 43 & 46 & $(34)$ \\
Benzo(b)naphtho(2,3-d)thiophene-6,11-quinone & 100 & 40 & 34 & $(34)$ \\
Chrysene-5,6-quinone & 19 & 100 & 28 & $(34)$ \\
Chrysene-1,4-quinone & 100 & 20 & 28 & $(34)$ \\
Aceanthrylene-1,2-quinone & 58 & 100 & 83 & $(34)$ \\
Benzo(a)pyrene-1,6-quinone & 100 & 34 & 16 & $(34)$ \\
Benzo(a)pyrene-3,6-quinone & 100 & 24 & 17 & $(34)$ \\
Benzo(a)pyrene-4,5-quinone & 72 & 100 & 25 & $(34)$ \\
Benzo(a)pyrene-6,12-quinone & 100 & 71 & 20 & $(34)$ \\
Benzo(a)pyrene-7,10-quinone & 100 & 10 & 11 & $(25)^{*}$ \\
Benzo(a)pyrene-1 1,12-quinone & 48 & 100 & - & $(25)^{*}$ \\
Benzo(e)pyrene-4,5-quinone & 47 & 100 & 40 & $(34)$ \\
& & & & \\
\hline
\end{tabular}

$\begin{array}{llll}\text { *recorded } & \text { at } & 25 & \mathrm{eV}\end{array}$

an elimination of $\mathrm{CHO}$, sulfur, $\mathrm{CHS}$, SO, $\mathrm{H}_{2} \mathrm{SO}_{2}$, and $\mathrm{CHSO}_{2}$, respectively from sulfones, and (M-16) (elimination of oxygen) from sulfoxides. The latter fragment is also found in the mass spectra of $\mathrm{N}$-oxides and epoxides. Tables 16 and 17 present MS data on some thiaarenes.

\section{(c) Applications}

GC/MS has been successfully applied to biochemical studies of PAH-metabolism. Stoming et al. $/ 24,40 /$ have devised a gas chromatographic assay of epoxide hydrolase activity with 3-me thylcholanthrene- 


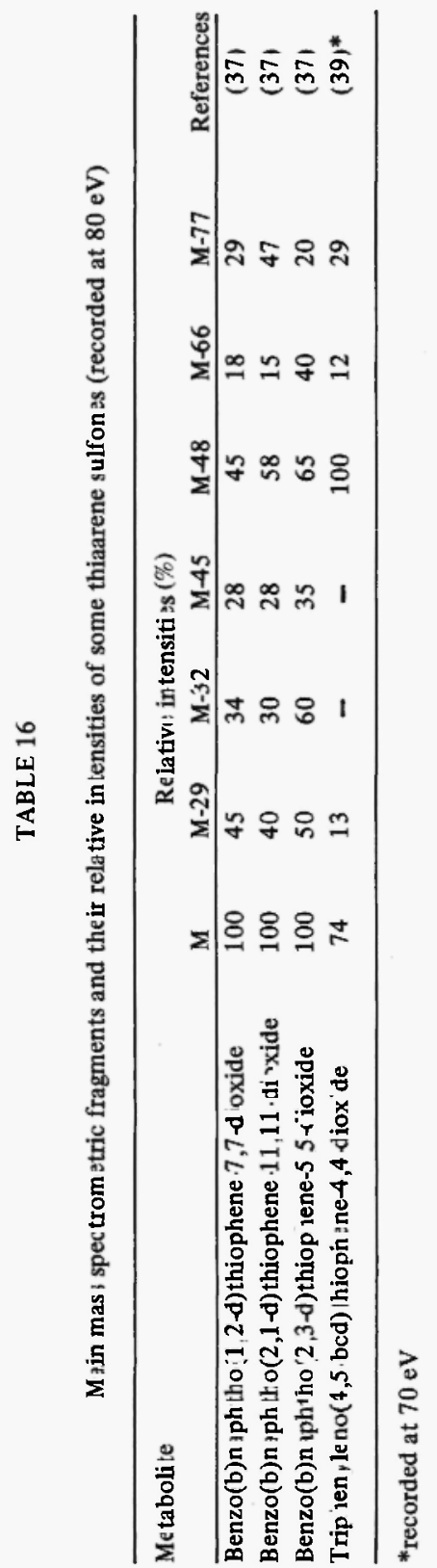


Main mass spectrometric fragments and their relative intensities of some thiaarene sulfoxides (recorded at $80 \mathrm{eV}$ )

\begin{tabular}{llll}
\hline Metabolite & \multicolumn{2}{c}{ Relative intensities.(\%) } \\
& M & M-16 & References \\
\hline Benzo(b)naphtho(1,2-d)thiophene-7-oxide & 28 & 100 & $(34)$ \\
Benzo(b)naphtho(2,1-d)thiophene-11-oxide & 34 & 100 & $(34)$ \\
Benzo(b)naphtho(2,3-d)thiophene-5-oxide & 22 & 100 & $(34)$ \\
\hline
\end{tabular}

11,12-oxide as substrate by determination of the resulting 11,12 -dihydrodiol after trimethylsilylation. Bettencourt et al. /26/ improved the sensitivity of the method by derivatizing the metabolites with bis-(chloromethyl)tetramethyldisilazane / chloromethyltrimethylchlorsilane / pyridine (2:1:4) and using a highly sensitive electron-capture detector or a CGC/MS combination. Under their experimental conditions concentrations of $1 \mathrm{ng} / \mathrm{mL}(=1 \mathrm{pg} / \mu \mathrm{L})$ of the incubation mix ture could be detected and evaluated.

Takahashi et al. have identified 3-methylcholanthrene related /41/ as well as a broad variety of benzo(a)pyrene metabolites $/ 25 /$.

In a series of papers Jacob et al. have studied the metabolism of a number of PAH with rat liver microsomes. They also studied the inducibility of $\mathrm{P} 450 / \mathrm{P} 448$ isocytochromes in rats after pretreatment with various xenobiotics such as $\mathrm{PAH}$, pesticides, and pharmaceuticals. After phenanthrene application they found 9,10-dihydroxy-9,10-dihydrophenanthrene to be the exclusive metabolite of phenanthrene in liver microsomes of untreated rats, whereas pretreatment with $\mathrm{PAH}$ and related compounds resulted in different rates of additional oxidation at the 1,2- and 3,4-position. Moreover, secondary metabolism to dihydrodiol epoxides, detected as triols, was observed $/ 28 /$. Evidence for the formation of the proximate and ultimate carcinogen of phenanthrene was also presented in that paper. A typical phenanthrene metabolite profile after P448 induction with chrysene is given in Fig. 6 .

In a study of the rat liver microsomal metabolism of pyrene 1-hydroxypyrene and 4,5-dihydroxy-4,5-dihydropyrene have been ob- 


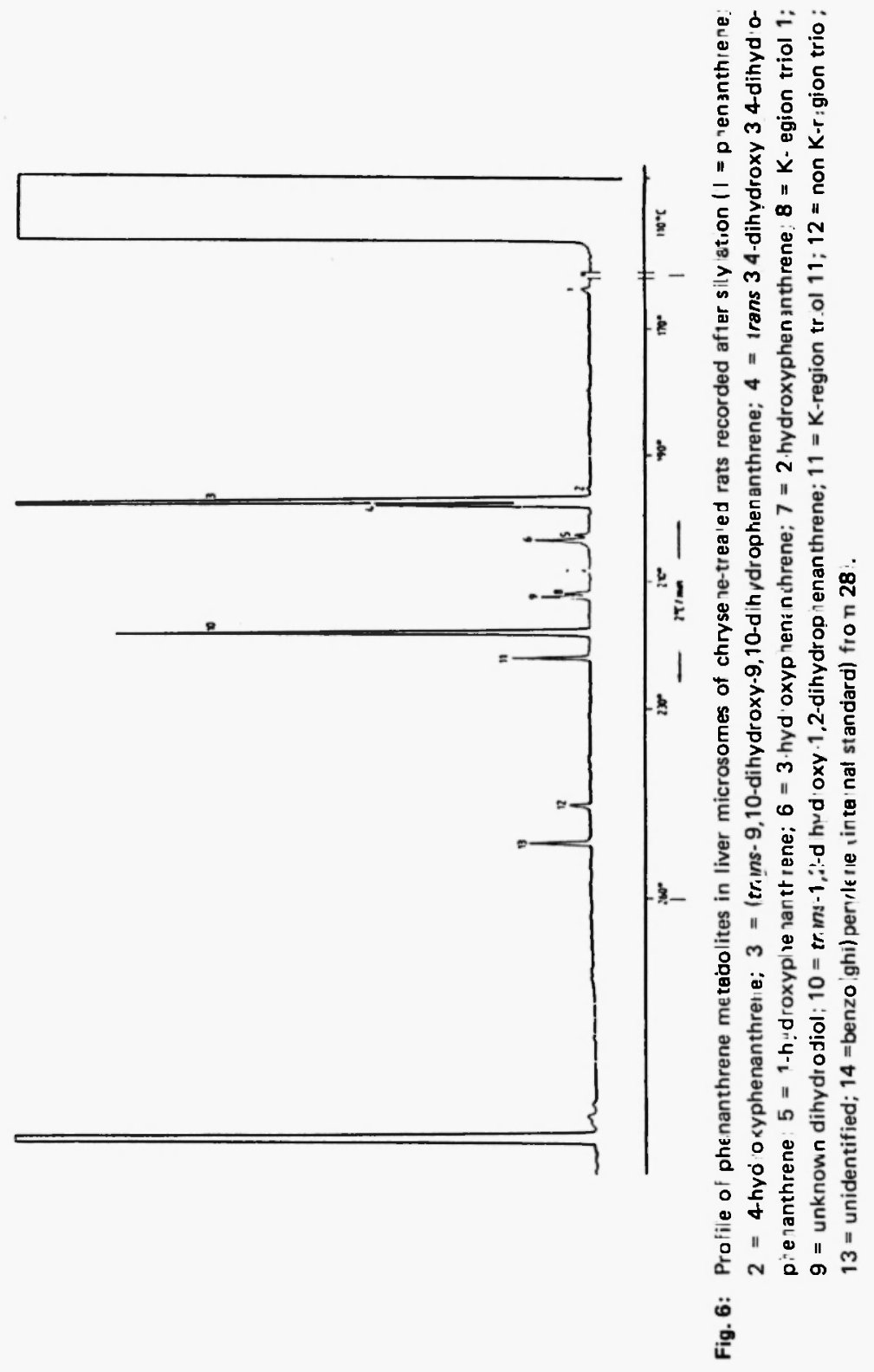


served to be the main metabolites apart from smaller amounts of two diphenols (tentatively identified as 1,6- and 1,8-dihydroxypyrene) and a triol $/ 31,42 /$ (see Figure 7).

Several CGC/MS investigations of the metabolism of benz(a)anthracene $/ 29,43,47 /$ have demonstrated that the molecule can be at tacked at all sites by liver microsomes from variously pretreated rats (at the 1,2-, 3,4-, 5,6-, 8,9-and the 10,11-position), whereas microsomes of untreated rats convert benz(a)anthracene almost exclusively to the 10,11-dihydrodiol. The time course of the rat liver microsomal metabolism of benz(a)anthracene /44/ as well as the dose-dependent induction of this metabolism by benzo(k)fluoranthene have been studied by means of CGC/MS /45/.

Two papers report on the rat liver microsomal activation of chrysene using GC/MS for detection and identification of the metabolites $130,46 /$. Oxidation preferentially takes place at the 1,2-and 3,4-position. The formation of secondary metabolites including the ultimate carcinogen of chrysene has been reported /30/. Figure 8 presents a typical gas chromatogram of a chrysene metabolite profile in liver microsomes of PCB-treated rats.

GC/MS analysis of the benzo(e)pyrene metabolite profile as formed by rat liver microsomes showed the formation of 1 - and 3 hydroxybenzo(e)pyrene and 4,5-dihydoxy-4,5-dihydrobenzo(e)pyrene as well as the proximate carcinogen of this PAH. The ultimate carcinogen (9,10-dihydroxy 11,12-epoxy-9,10,11,12-tetrahydrobenzo(e)pyrene), however, is not found which may explain the inefficiency of this PAH as a carcinogen. Pretreatment of the animals by various xenobiotics resulted in more complex patterns and induced also the formation of the 9,10-dihydrodiol /32,33/. A liver microsomal benzo(e)pyrene metabolite profile from benzonaphthoflavone-treated rats is presented in Figure 9.

Recently, the rat liver microsomal metabolism of indeno $(1,2,3$. cd)pyrene has been investigated by CGC/MS / $34 /$ which confirmed the findings obtained with HPLC / 18,19/.

The metabolism of some heterocyclic polycyclic aromatic compounds such as azaarenes and thiaarenes has also been studied by CGC/MS. Conversion of benz(a)- and benz(c)acridine to various phenols, dihydrodiols and triols has been reported for both of them, whereas 


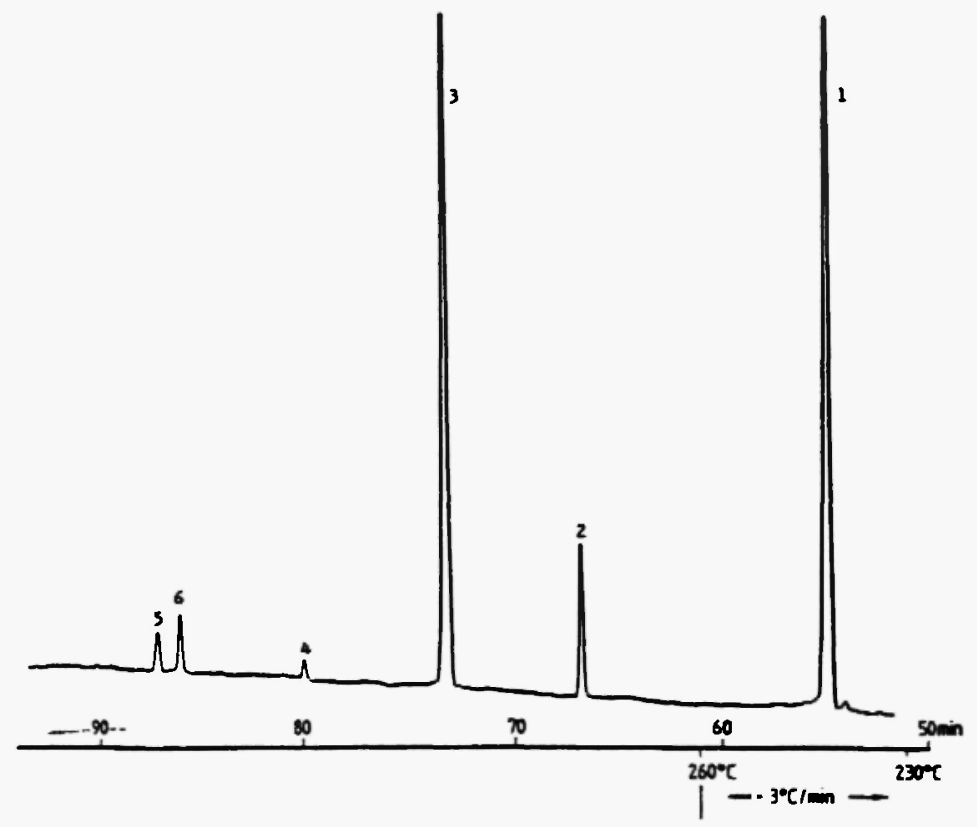

Fig. 7: Profile of pyrene metabolites in liver microsomes of untreated rats recorded after silylation $(1=$ pyrene; $2=$ trans 4,5 -dihydroxy-4,5dihydropyrene; $3=1$-hydroxypyrene; $4=$ K-region triol (tentatively identified as 1,4,5-trihydroxy-4,5-dihydropyrene); 5 = dihydroxypyrene (tentatively identified as 1,8-dihydroxypyrene); 6 = dihydroxypyrene (tentatively identified as 1,6-dihydroxypyrene) (from 31 ). 


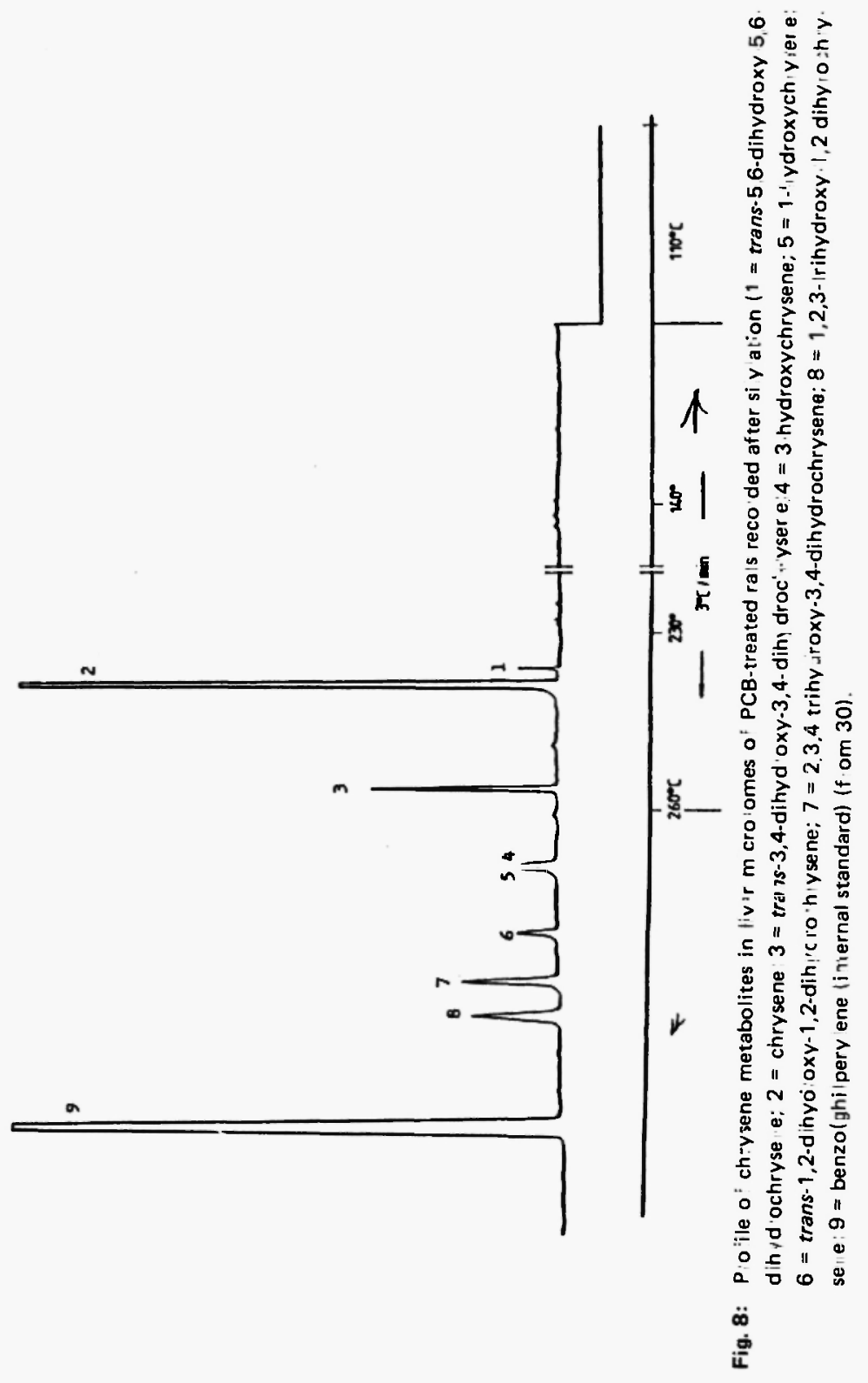




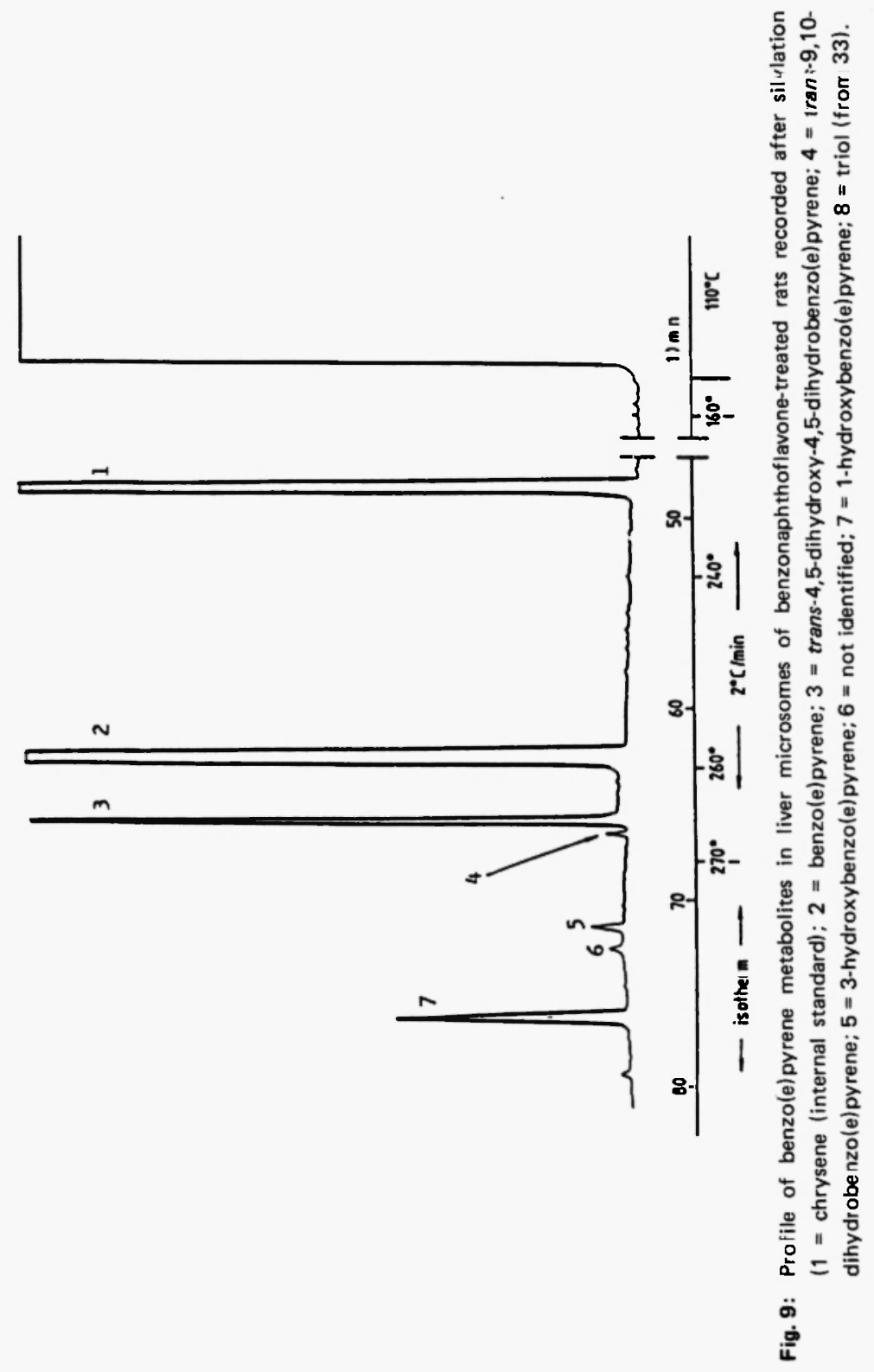


$\mathrm{N}$-oxidation only was observed in the case of benz(c)acridine $/ 35,36 /$. A similar CGC/MS study with 4 different thiaarenes (benzo(b)naphtho(1,2-d)-, -(2,1-d)-, and -(2,3-d)thiophene as well as triphenyleno(4,5bcd)thiophene) demonstrated that the compounds are preferentially converted to sulfoxides and sulfones by rat liver microsomes $/ 37 /$.

GC/MS has also been used in studying PAH-metabolism in cell and tissue cultures $/ 48,49 /$. Apart from the formation of phenols and dihydrodiols, a methyl-transfer was detected by GC/MS in the case of the substrate benz(a)anthracene with lung cell cultures (see Figure 10). This extends the findings with rat liver microsomes and shows that, as expected, additional enzyme systems for the primary metabolism of PAH exist in complete cell systems. 


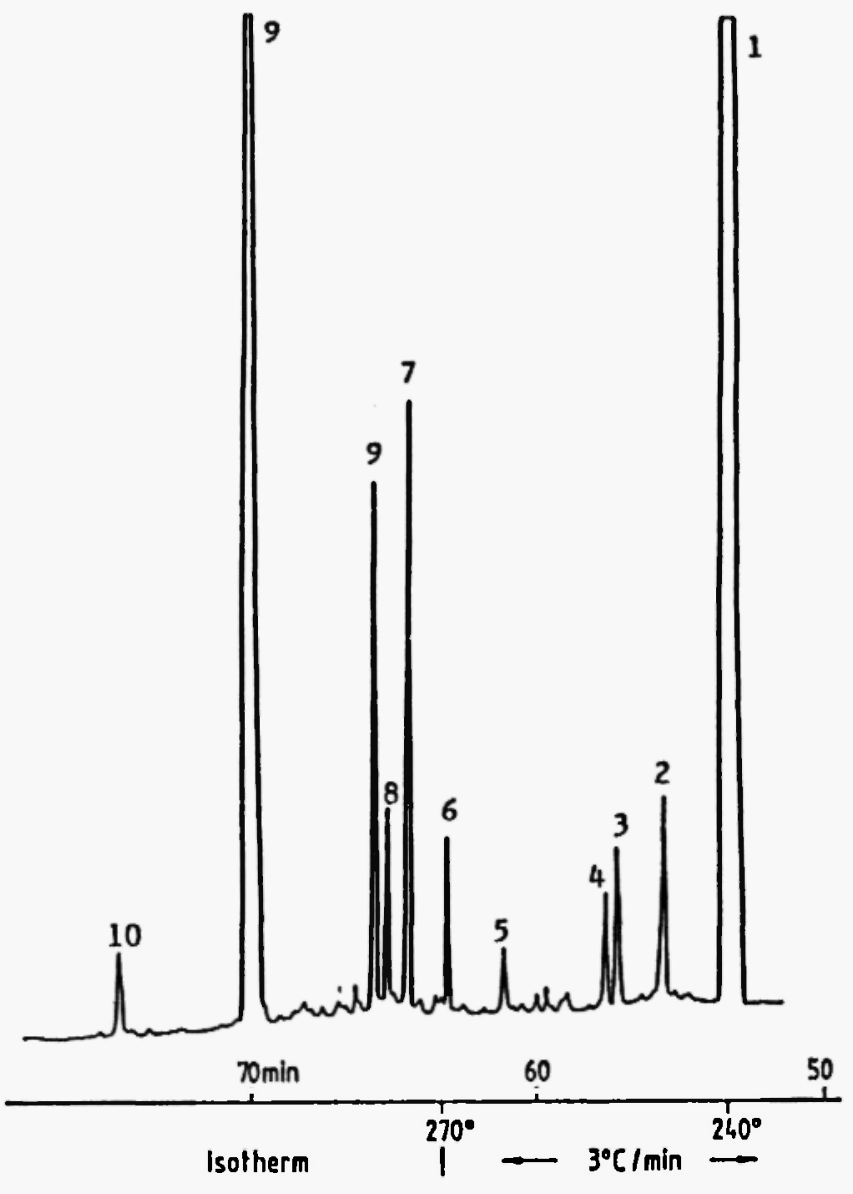

Fig. 10: Profile of benz(a)anthracene metabolites in fetal Syrian hamster cells after silylation ( 1 = benz(a)anthracene; 2 = 12-methylbenz(a)anthracene; 3 and $4=$ not identified; $5=11$-hydroxybenz(a)anthracene; $6=$ not identified $(\mathrm{M}=540) ; \quad 7=$ trans-10,11-dihydroxy-10,11-dihydrobenz(a)anthracene; $8=$ not identified; $9=$ trans-8,9-dihydroxy-8,9dihydrobenz(a)anthracene; $10=$ indeno $(1,2,3-\mathrm{cd})$ fluoranthene (internal standard); $11=8,9,10$-trihydroxy-8,9-dihydrobenz(a)anthracene) (from 49). 


\section{REFERENCES}

1. SELKIRK, J.K., Adv. Chromatogr., 16: 1 (1978).

2. YANG, S.K., DEUTSCH, J. and GELBOIN, H.V. "Benzo(a)pyrene metabolism: Activation and detoxification", in "Polycyclic Hydrocarbons and Cancer, Vol. 1" (Eds.) Gelboin, H.V. and Tso, P.O.P., Academic Press, 205-231 (1978).

3. THAKKER, D.R., NORDQVIST, M., YAGI, H., LEVIN, W., RYAN, D., THOMAS, P., CONNEY, A.H. and JERINA, D.M. "Comparative metabolism of a series of polycyclic aromatic hydrocarbons by rat liver microsomes and purified cytochrome P-450", in "Polynuclear Aromatic Hydrocarbons" (Eds.) Jones, P.W. and Leber, P., Ann Arbor Science Publ., Ann Arbor, 455472 (1979).

4. LAVOIE, E.J., TULLEY-FREILER, L., BEDENKO, V., GIRACH, Z. and HOFFMANN, D. "Comparative studies on the tumor initiating activity and metabolism of methylfluorenes and methylbenzofluorenes" in "Chemical Analysis and Biological Fate: Polynuclear Aromatic Hydrocarbons" (Eds.) Cooke, M. and Dennis A.J., Battelle Press, Columbus/Ohio, 417427 (1981).

5. NORDQVIST, M., THAKKER, D.R., VYAS, K.P., YAGI, H., LEVIN, W., RYAN, D., THOMAS, P.E., CONNEY, A.H. and JERINA, D.M. Mol. Pharmacol., 19; 168 (1981).

6. RICE, J.E., BEDENKO, V., LAVOIE, E.J. and HOFFMANN, D. "Studies on the metabolism of fluoranthene, 2-methylfluoranthene, and 3-methylfluoranthene" in "Polynuclear Aromatic Hydrocarbons: Formation, Metabolism and Measurement" (Eds.) Cooke, M. and Dennis, A.J., Battelle Press, Columbus-Richland, 1009-1020 (1983).

7. HODGSON, R.M., WESTON, A., CARY, P.D., VIGNY, P. and GROVER, P.L. "The metabolic activation of chrysene" in "Polynuclear Aromatic Hydrocarbons: Mechanisms, Methods and Metabolism" (Eds.) Cooke, M. and Dennis, A.J., Battelle Press, Columbus/Richland, $541-560$ (1985).

8. HECHT, S.S., MAZZARESE, R., AMIN, S., LAVOIE, E. and HOFFMANN, D. "On the metabolic activation of 5-methylchrysene" in "Polynuclear Aromatic Hydrocarbons" (Eds.) Jones, P.W. and Leber, P., Ann Arbor Science Publ., Ann Arbor, 733-754 (1979).

9. SHEIKH, Y.M., INBASEKARAN, M.N., DANIEL, F.B., CAZER, F.D., HART, R.W. and WITIAK, D.T. "A study of the 7,12-dimethylbenz(a)anthracene (DMBA) Bay Region involvement in the production of carcinogen and mutagen metabolites" in "Polynuclear Aromatic Hydrocarbons: Chemical and Biological Effects" (Eds.) Bjфrseth, A. and Dennis, A.J., Battelle Press, Columbus/Ohio, 689-731 (1980).

10. YANG, S.K., CHOU, M.W., WISLOCKI, P.G. and LU, A.Y.H. "Metabolism of 7,12-dimethylbenz(a)anthracene: Quantification of metabolite formations in rat liver microsomes and a reconstituted enzyme system containing highly 
purified cytochrome P-450 or P-448" in "Polynuclear Aromatic Hydrocarbons: Chemistry and Biological Effects" (Eds.) Bjprseth, A. and Dennis, A.J., Battelle Press, Columbus/Ohio, 733-752 (1980).

11. ITTAH, Y., THAKKER, D.R., LEVIN, W., CROISY-DELCEY, M., RYAN, D.E., THOMAS, P.E., CONNEY, A.H. and JERINA, A.H., Chem.-Biol. Interact., 45: 15 (1983).

12. GOLD, A., SCHULTZ, I. and EISENSTADT, E. "Synthesis and metabolism of cyclopenta(cd)pyrene" in "Polynuclear Aromatic Hydrocarbons" (Eds.) Jones, P.W. and Leber, P., Ann Arbor Science Publ., Ann Arbor, 695-704 (1979).

13. LI, X.-C., FU, P.P., CHOU, M.W. and YANG, S.K. "Metabolism of the potent carcinogen cholanthrene" in "Polynuclear Aromatic Hydrocarbons: Formation, Metabolism and Measurement" (Eds.) Cooke, M., and Dennis, A.J., Battelle Press, Columbus/Richland, 809-818 (1983).

14. THAKKER, D.R., LEVIN, W., STOMING, T.A., CONNEY, A.H. and JERINA, D.M., "Metabolism of 3-methylcholanthrene by rat liver microsomes and a highly purified monooxygenase system with and without epoxide hydrase" in" Carcinogenesis Vol. 3: Polynuclear Aromatic Hydrocarbons" (Eds.) Jones, P.W. and Freudenthal, R.I., Raven Press, New York, 253-264 (1978).

15. SELKIRK, J.K. and MACLEOD, M.C. "Metabolism and macromolecular binding of benzo(a)pyrene and its noncarcinogenic isomer benzo(e)pyrene in cell culture" in "Polynuclear Aromatic Hydrocarbons" (Eds.) Jones, P.W. and Leber, P., Ann Arbor Science Publ., Ann Arbor, 21-35 (1979).

16. HECHT, S.S., LAVOIE, E., AMIN, S., BEDENKO, V. and HOFFMANN, D. "On the metabolic activation of the benzofluoranthenes" in "Polynuclear Aromatic Hydrocarbons: chemical and Biological Effects" (Eds.) Bjørseth, A. and Dennis, A.J., Battelle Press, Columbus/Ohio, $417-433$ (1980).

17. AMIN, S., HUSSAIN, N., HUIE, K., BALANIKAS, G., RICE, J.E., LAVOIE, E.J. and HECHT, S.S. "Synthesis and identification of dihydrodiol metabolites of benzo(b)fluoranthene and benzo(j)fluoranthene" in "Polynuclear Aromatic Hydrocarbons; Mechanisms, Methods and Metabolism" (Eds.) Cooke, M. and Dennis, A.J., Battelle Press, Columbus/Richland, 99-111 (1985).

18. RICE, J.E., COLEMAN, D.T., HOSTED, T.J., LAVOIE, E.J., MCCAUSTLAND, D.J. and WILEY, J.C. "On the metabolism, mutagenicity, and tumor-initiating activity of indeno( $1,2,3-\mathrm{cd})$ pyrene" in "Polynuclear Aromatic Hydrocarbons: Mechanisms, Methods and Metabolism" (Eds.) Cooke, M. and Dennis, A.J., Battelle-Press, Columbus/Richland, 1097-1109 (1985).

19. RICE, J.E., COLEMAN, D.T., HOSTED, T.J., LAVOIE, E.J., MCCAUSTLAND, D.J. and WILEY, J.C., Cancer Res., 45: 5421 (1985).

20. MACNICOLL, A.D., BURDEN, P.M., RATTLE, H., GROVER, P.L. and SIMS, P., Chem.-Biol. Interactions, 27: 365 (1979). 
21. HECHT, S.S., LA VOIE, E.J., BEDENKO, V., HOFFMANN, D., SARDELLA, D.J., BOGER, E. and LEHR, R.E. "On the metabolic activation of dibenzo(a,i)pyrene and dibenzo(a,h)pyrene" in "Chemical Analysis and Biological Fate: Polynuclear Aromatic Hydrocarbons" (Eds.) Cooke, M. and Dennis, A.J., Battelle Press, Columbus/Ohio, 43-54 (1981).

22. BAIRD, W.A., CHEMERYS, R., ERICKSON, A.A., CHERN, C.J., and DIAMOND, L. "Differences in pathways of polycyclic aromatic hydrocarbon metabolism as detected by analysis of the conjugates formed" in "Polynuclear Aromatic Hydrocarbons" (Eds.) Jones, P.W. and Leber, P., Ann Arbor Science Publ., Ann Arbor, 507-516 (1979).

23. MACLEOD, M.C., MOORE, C.J. and SELKIRK, J.K. "Analysis of watersoluble conjugates produced by hamster embryo cells exposed to polynuclear aroma tic hydrocarbons" in "Polynuclear Aromatic Hydrocarbons" Chemistry and Biological Effects" (Eds.) Bjørseth, A. and Dennis, A.J., Battelle Press, Columbus/Ohio, 9-23 (1980).

24. STOMING, T.A. and BRESNICK, E., Science, 181: 951 (1973).

25. TAKAHASHI, G., KINOSHIT A, K., HASHIMOTO, K., and YASUHIRA, K., Cancer Res., 39: 1814 (1979).

26. BETTENCOURT, A., LHOEST, C., ROBERFROID, M. and MERCIER, M., J. Chromatogr., 134: 323 (1977).

27. WONG, L.K., WANG, C.-L.A. and DANIEL, F.B., Biomed. Mass Spectrom., 6: 305 (1979).

28. JACOB, J., SCHMOLDT, A. and GRIMMER, G., Toxicology 25: 333 (1982).

29. JACOB, J., SCHMOLDT, A. and GRIMMER, G., Hoppe-Seyler's Z. Physiol. Chem., 362: 1021 (1981).

30. JACOB, J., SCHMOLDT, A. and GRIMMER, G., Arch. Toxicol, 51: 255 (1982).

31. JACOB, J., GRIMMER, G., RAAB, G, and SCHMOLDT, A., Xenobiotica, 12: 45 (1982).

32. JACOB, J., SCHMOLDT, A., GRIMMER, G., HAMANN, M., and RAAB, G. "Benzo(e)pyrene: Identification and quantitative analysis of metabolites formed by liver microsomes of variously pretreated rats by means of capillary gas chromatography/mass spectrometry" in "Polynuclear Aromatic Hydrocarbons: Mechanisms, Methods and Metabolism" (Eds.) Cooke, M. and Dennis, A.J., Battelle Press, Columbus/Ohio, 627-641 (1985).

33. JACOB, J., SCHMOLDT, A. and GRIMMER, G., Carcinogenesis, 4: 905 (1983).

34. JACOB, J., unpublished results (1985).

35. JACOB, J., SCHMOLDT, A., RAAB, G., KOHBROK, W. and GRIMMER, G. "Rat liver and lung microsomal metabolism of benz(a)-and benz(c)-acridine" in "Polynuclear Aromatic Hydrocarbons: Formation Metabolism and Measurement" (Eds.) Cooke, M. and Dennis, A.J., Battelle Press, Columbus/Ohio, 637-647 (1983). 
36. JACOB, J., SCHMOLDT, A., KOHBROOK, W., RAAB, G. and GRIMMER, G., Cancer Lett., 16: 297 (1982).

37. JACOB, J., SCHMOLDT, A., and GRIMMER, G., Cancer lett., 32:107 (1986).

38. GRIMMER, G., DETTBARN, G. and JACOB, J., unpublished results.

39. KLEMM, L.H. and LAWRENCE, R.F., J. Heterocyclic Chem., 16: 599 (1979).

40. STOMING, T.A., KNAPP, D. and BRESNICK, E., Life Sci., 12: 425 (1973).

41. TAKAHASHI, G., Jap. J Cancer Res., 69: 437 (1978).

42. JACOB, J., GRIMMER, G. and SCHMOLDT, A. "Comparison of the metabolic profiles of pyrene and benz(a)anthracene in rat liver and lung by glass capillary gas chromatography/mass spectrometry" in "Polynuclear Aromatic Hydrocarbons: Physical and Biological Chemistry" (Eds.) Cooke, M., Dennis, A.J., and Fisher, G.L., Battelle Press, Columbus/Ohio, 383-388 (1982).

43. JACOB, J., GRIMMER, G. and SCHMOLDT, A., Cancer Lett., 14: 175 (1981).

44. JACOB, J., SCHMOLDT, A. and GRIMMER, G., Carcinogenesis, 2: 395 (1981).

45. SCHMOLDT, A., JACOB, J. and GRIMMER, G., Cancer Lett., 13: 249 (1981).

46. JACOB, J., KARCHER, W., GRIMMER, G., SCHMOLDT, A. and HAMANN, $M$. "The influence of various monooxygenase inducers on rat liver microsomal chrysene oxidation" in "Polynuclear Aromatic Hydrocarbons: Chemistry, Characterization and Carcinogenesis" (Eds.) Cooke, M. and Dennis, A.J., Battelle Press, Columbus/Richland, 417-426 (1986).

47. JACOB, J., SCHMOLDT, A., RAAB, G., HAMANN, M. and GRIMMER, G., Cancer Lett., 20: 341 (1983).

48. JACOB, J., GRIMMER, G., RICHTER-REICHHELM, H.-B. and EMURA, M., VDI-Berichte, 358: 273 (1980).

49. GRIMMER, G., JACOB, J., SCHMOLDT, A., RAAB, G., MOHR, U. and EMURA, M. "Metabolism of Benz(a)anthracene in hamster lung cells in culture in comparison to rat liver microsomes" in "Polynuclear Aromatic Hydrocarbons: Mechanism, Methods, and Metabolism" (Eds.) Cooke, M. and Dennis, A.J., Battelle Press, columbus/Ohio, 521-532 (1985). 